San Jose State University

SJSU ScholarWorks

Master's Theses

Master's Theses and Graduate Research

Spring 2012

\title{
Maintenance of Polish Language and Culture among First Generation Polish Immigrants Living in the Southern San Francisco Bay Area, California.
}

Dominika Bialek

San Jose State University

Follow this and additional works at: https://scholarworks.sjsu.edu/etd_theses

\section{Recommended Citation}

Bialek, Dominika, "Maintenance of Polish Language and Culture among First Generation Polish Immigrants Living in the Southern San Francisco Bay Area, California." (2012). Master's Theses. 4121. DOI: https://doi.org/10.31979/etd.m4hw-qtfv https://scholarworks.sjsu.edu/etd_theses/4121

This Thesis is brought to you for free and open access by the Master's Theses and Graduate Research at SJSU ScholarWorks. It has been accepted for inclusion in Master's Theses by an authorized administrator of SJSU ScholarWorks. For more information, please contact scholarworks@sjsu.edu. 


\title{
MAINTENANCE OF POLISH LANGUAGE AND CULTURE AMONG FIRST GENERATION POLISH IMMIGRANTS LIVING IN THE SOUTHERN SAN FRANCISCO BAY AREA, CALIFORNIA
}

\author{
A Thesis \\ Presented to \\ The Faculty of the Department of Linguistics and Language Development \\ San José State University \\ In Partial Fulfillment \\ of the Requirements for the Degree \\ Masters of Arts
}

by

Dominika Bialek

May 2012 
(C) 2012

Dominika Bialek

ALL RIGHTS RESERVED 
The Designated Thesis Committee Approves the Thesis Titled

MAINTENANCE OF POLISH LANGUAGE AND CULTURE AMONG FIRST GENERATION POLISH IMMIGRANTS LIVING IN THE SOUTHERN SAN FRANCISCO BAY AREA, CALIFORNIA

by

Dominika Bialek

APPROVED FOR THE DEPARTMENT OF LINGUISTICS AND LANGUAGE DEVELOPMENT

SAN JOSÉ STATE UNIVERSITY

May 2012
Dr. Swathi Vanniarajan
Department of Linguistics and Language Development
Dr. Scott Phillabaum
Department of Linguistics and Language Development
Dr. Soteria Svorou
Department of Linguistics and Language Development 


\begin{abstract}
MAINTENANCE OF POLISH LANGUAGE AND CULTURE AMONG FIRST GENERATION POLISH IMMIGRANTS LIVING IN THE SOUTHERN SAN FRANCISCO BAY AREA, CALIFORNIA
\end{abstract}

\author{
by Dominika Bialek
}

The focus of this thesis research is to investigate the extent to which first generation Polish immigrants living in the southern San Francisco Bay Area in California maintain their native Polish language and culture. Qualitative data were collected in the form of interviews and survey questionnaires. The major findings show that in this small immigrant community (1) maintenance of Polish language and culture happens primarily at home; (2) females married to first generation Polish immigrants are more likely than others to maintain Polish language and culture; (3) the small size of the Polish community, knowledge of English at the time of arrival, and a high level of education together contribute to first generation Polish immigrants' shift to the English language and American culture. 


\section{ACKNOWLEDGMENTS}

I would like to thank Dr. Dulce Gray and other wonderful people who have been helping me during my journey.

I would like to dedicate this thesis to my brother, Adrian, who died tragically on February $28^{\text {th }}$ this year. 


\section{Table of Contents}

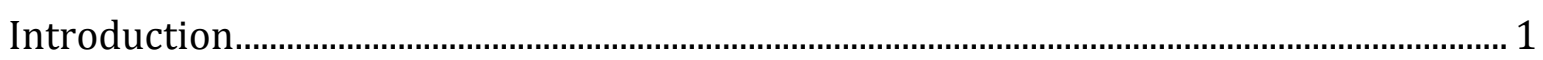

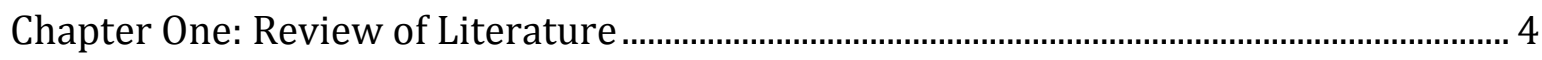

Chapter Two: Factors Influencing Maintenance of Language and Culture .........................17

Chapter Three: Polish Culture in Polish Immigrant Communities in the United

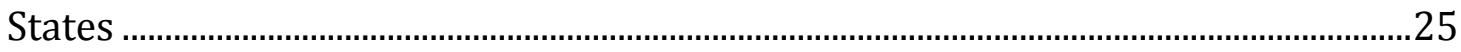

Polish Language and Cultural Norms ..............................................................................27

Resources Available for Maintaining Polish Language and Polish Culture in the

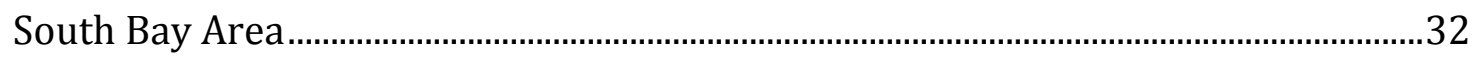

Chapter Four: Methodology and Findings .................................................................................36

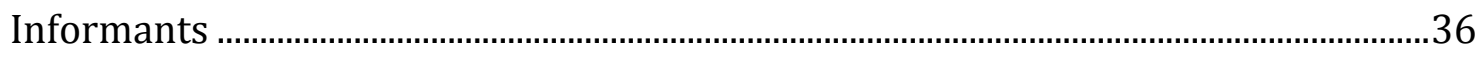

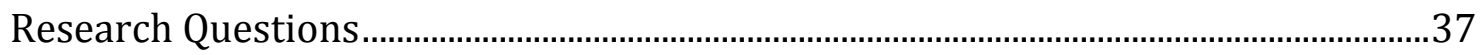

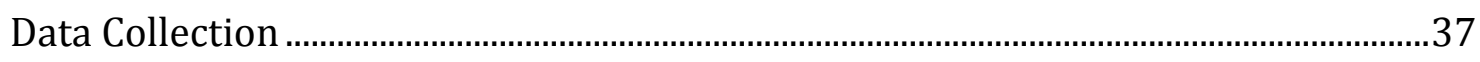

Findings Regarding Individual Informants......................................................................38

Alina (female, about 32 years in the U.S.)..................................................................39

Arek (male, about 25 years in the U.S.). …………..................................................4

Agnieszka (female, about 12 years in the U.S.). …………………………………...4

Monika (female, about 11 years in the U.S.)..............................................................53

Kasia (female, about 8 years in the U.S.) …………………………………………........ 57

Dariusz (male, about 7 years in the U.S.).................................................................61

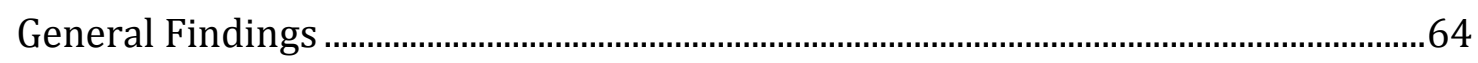

Use of Polish language...................................................................................................64 
Intergenerational transmission of Polish language and culture

The role of community factors in the maintenance of Polish language and culture.

The Role of demographic factors in the maintenance of Polish language and culture.

The role of attitudes and perceptions in the maintenance of Polish language and culture.

Chapter Five: Conclusions and Direction for Further Research .79

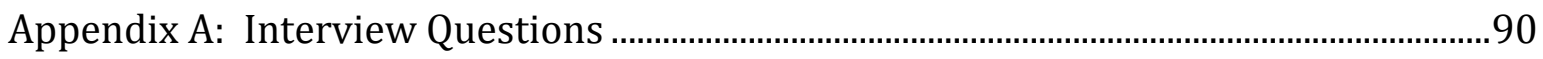

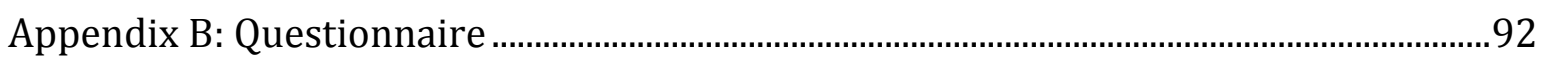

Appendix C: Human Subjects Committee Letter of Approval ........................................... 102

Appendix D: Consent Form for Participants...................................................................... 103 


\section{LIST OF TABLES}

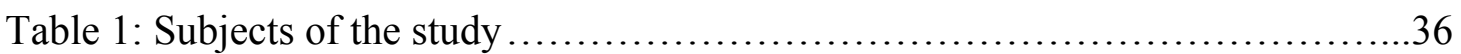




\section{Introduction}

When I first came to the United States from Poland in 2006 and started living in the southern San Francisco Bay Area (known as the South Bay Area), I immediately became acquainted with the small Polish community, but since I already knew English well, and since my goal in coming to the United States was to continue to improve my English speaking skills, I did not seek the company of other Polish people, nor did I need to rely on this Polish community. Although I did not become an active member of the small Polish community, I managed to maintain a firm sense of my Polish cultural and ethnic identity. However, as time passed I noticed that my attitudes and behaviors began to change. For example, when I first arrived in the South Bay Area, I looked at American people and their culture through the eyes of an outsider who had difficulty comprehending the unknown. With time I got used to American ways, and I accepted many of the American cultural practices that had surprised me at the beginning. What's more, I started looking at my native Polish culture from an American perspective. Noticing the changes in my attitudes and cultural identity led me to become interested in examining the various shifting elements of an immigrant's identity, particularly the crucial ones: language and culture.

Since my own experience as an immigrant is recent and does not yet reveal longlasting effects, I was especially interested in understanding the long-term consequences and processes involved in language and cultural maintenance. Thus, I decided to study a sample of first generation Polish immigrants who have been living in the South Bay Area longer than I. I started my research by observing that the South Bay Area is highly 
multicultural and that some minority groups preserve their language and culture more evidently than some other groups. That observation piqued my interest about the Polish community; I became curious about the factors that may influence Polish people in this part of the United States to maintain their language and culture.

This thesis is my scholarly attempt to investigate the factors that help determine the extent to which first generation Polish immigrants in the South Bay Area maintain their native language and culture. I collected qualitative data in the form of interviews and survey questionnaires. I describe my study in this manuscript, which is divided into five chapters. Chapter One contains a review of the literature on the maintenance of minority languages and cultures. Chapter Two discusses factors influencing language and culture maintenance among Polish immigrants in the South Bay Area. Chapter Three describes Polish language, culture, Polish immigrant communities in the United States, and the Polish language and cultural resources available to immigrants in the South Bay area. Chapter Four describes the design, subjects, and the major findings of this study. Chapter Five contains conclusions and suggestions for further research.

A number of studies (Li, 2006; Luo and Wisemen, 2000; Ying, 1995; Zhang, 2008) on language maintenance and shift in the United States have focused on large and cohesive immigrant groups such as Chinese, Japanese, Korean, and Mexican (Gibbons \& Ramirez, 2004; Hayashi, 2006; Kim, 2006; Schlecter \& Bayley, 1997; Shin, 2006; Yamamoto, 2001 and 2002). These studies examine how the maintenance of minority languages and cultures occurs in large immigrant communities; however, little is known about how this maintenance happens in smaller immigrant communities. Even though 
each of these research projects has provided information that contributes to our understanding of the maintenance of language and culture, there is a gap in the literature identifying factors affecting maintenance of language and culture among the members of small European communities in the United States. Currently, there is no study to my knowledge that focuses exclusively on how first-generation Polish immigrants maintain their Polish language and culture in the United States. Certainly, there is no study that covers exclusively the small community of Polish immigrants living in the South Bay area in northern California. Poland was a communist state from the end of World War II until the end of the 1980s. During that time many emigrants fled Poland and chose the United States as their new country of residence. A few settled in the South Bay Area. They are the informants in my research, and my aim is to examine the degree to which they maintain their Polish language and culture as immigrants in this part of the United States. 


\section{Chapter One: Review of Literature}

The inscription at the base of the Statue of Liberty (a poem written in 1883 by Emma Lazarus) is famous because it affirms that the United States of America welcomes all immigrants with open arms. The last four lines of Lazarus' poem are particularly significant to many people around the world:

Give me your tired, your poor, Your huddled masses, yearning to breathe free, The wretched refuse of your teeming shore, Send these, the homeless, tempest-tossed to me, I lift my lamp beside the golden door!

These lines claim that the United States wants immigrants who are "poor," "wretched," and "homeless." The implication is that the immigrants will gain greatly in the land of opportunities. This description of immigrants may be true to a large extent so far as the material lives of some immigrants are concerned. However, when we consider the "huddled masses," we see that they do not come empty-handed; they bring with them, apart from knowledge and education, a wealth of culture, language, and experiences.

One of the major issues that these immigrants face in their adopted country is whether to maintain their first language and culture and to pass them onto their children as cultural heritage, or to shift to the host language and host culture. For some of those who shift and adopt the host language and culture, the process may be psychologically unnerving, particularly for the first generation, because making such a choice entails opting to adopt a new identity in both language use and culture. Since language and culture are intricately woven, many immigrants either change both or none. According to 
Kramsch (1998), language expresses, embodies, and symbolizes cultural reality.

Language expresses cultural reality, because members of a language community use the same words to express their attitudes and beliefs. Language embodies cultural reality, because speakers of a language in a community create experience by communicating in their language. And, language symbolizes external reality because it plays a major role in defining the speaker's identity. Consequently, as Fishman (1991) points out, "the destruction of a language is the destruction of a rooted identity": change of identity under the influence of the host society leads to a shift towards the language and culture of the host society (p. 4).

Language maintenance and language shift lie on a continuum and they may represent the opposite ends of the same spectrum: in a new country the new immigrants may or may not maintain their first language. Guardado (2002) underscores this view: "Loss and maintenance should be seen on a continuum, rather than as a dichotomy," because language loss occurs over a period of time and can be experienced in various degrees by different individuals and communities (p. 342). Moreover, Fishman (1972), a pioneer in language maintenance studies, claims that language maintenance and language shift are inseparable from socio-psychological processes. He defines language maintenance and language shift as ongoing psychological, social, or cultural processes experienced by populations who utilize more than one speech variety for intra-group purposes (Fishman, 1972). Fishman claims that maintenance of a language or shift towards another language is intertwined with psychological and sociocultural factors. In 
other words, it is impossible to talk about language maintenance or shift without talking about psychological and sociocultural processes such as acculturation or assimilation.

In new immigrant communities, language shift is generally much more common than language maintenance. In fact, language shift is inevitable. Regardless of the maintenance efforts, language shift happens because the subsequent generations always have less in common with their parents' or forefathers' language and culture (Portes \& Rumbaut, 2001). Fishman (1966) distinguishes the first generation from the second generation, and the third generation from the first and second generations. The first generation is foreign born; the second generation is native born of foreign or mixed parentage; the third generation is native born of native parentage; therefore the first generation is completely different from the other two generations. According to Fishman (1966), by the third generation language shift is usually complete.

While the definition used by Fishman (1966) takes into consideration the experience shared by new immigrants, their children, and grandchildren, Erdmans' (1995) definition draws on differences between the new immigrants and their descendants. Erdmans (1995) distinguishes the first generation new immigrants from the "ethnics" - the immigrants' children and grandchildren born in a new country. She points out that these two groups are not only different, but also have differing needs.

First, disparate cultural identities emerge because immigrant culture is embedded in the homeland, while ethnic culture is constructed over generations in the context of the host country. Second, immigrants and ethnics have different needs: the newcomers need to learn the culture of the host society, the established ethnics need to maintain an attachment to the culture of the home country. The findings suggest that ancestry does not always function as a basis for solidarity between immigrant and ethnic populations. (p. 604) 
My study does not consider second and third generation Polish immigrants (the "ethnics"); instead, it focuses only on the first generation (new immigrants) for whom language maintenance is more likely than it is for the subsequent generations.

Immigrants may define their identity within their own culture and language or within the target culture and language. If they have positive attitudes towards their own group, then they usually see their native language and culture as key elements of their identity and maintain them. If they see their native language and culture as problems preventing them from succeeding in the larger society, then they may want to give them up. In such cases, they may develop positive attitudes towards the members of the host group and identify with them. This may result in a shift towards the majority language and majority culture. In contrast, if they have positive attitudes towards their own group and the target group, then they may prefer to maintain their native language and culture and at the same time shift towards the target language and culture. Of course, race, history and political circumstances in the home country as well as the United States' relationship with that home country influence immigrants' perceptions of their options.

Immigrants, such a the first generation Polish community in the South Bay area that I study, experience pressure to adopt the host language and culture in order to have access to the benefits of being in the United States. Such new immigrants may feel that they have the option to define their identity in relation to their native and second culture. These new immigrants may initially experience cognitive dissonance which is prompted by incompatibility between the environment in which they grew up and the one in which 
they are attempting to start a new life. Cognitive dissonance is defined as an uncomfortable feeling, which occurs when a person simultaneously holds two conflicting ideas, or is faced with two incompatible options. New immigrants face a conflict between the social norms that they grew up with and the brand new world where different norms apply. According to Festinger's (1959) theory of cognitive dissonance, once the dissonance is present, individuals will make adjustments in order to reduce the dissonance. To reduce the dissonance, new immigrants will either adopt the host culture, or maintain their first culture, or they will adopt a double or split identity. It is possible to have a double or split identity if the minority language and culture and the majority language and culture coexist peacefully in the host society. But even if the immigrants have shifted to the language of the majority, they may continue to consider their native language to be an essential part of their identity.

Gans (1979) uses the term "symbolic identity" to refer to a situation where, in spite of the fact that an immigrant's native language does not perform an instrumental function in his or her life, that immigrant continues to cherish his or her native language and culture and treats them as an important part of his or her cultural identity. Gans (1979) defines "symbolic ethnicity" as "voluntary, diverse or individualistic ethnicity," which "takes on an expressive rather than instrumental function in people's lives, becoming more of a leisure-time activity and losing its relevance, say, to earning a living or regulating family life" (p.9). An example of someone who holds symbolic identity is a first generation immigrant who marries a person from a different ethnic background and who rarely interacts with other members of his or her linguistic and cultural group. 
Symbolic identity is a step in the process of shifting from home to host language and culture. All of these factors may intersect or be present in isolation; they may be the result of immigrants' conscious or unconscious calculations of pros and cons, and of subtle and obvious complex interactions; all of these factors affect the continuum of how and why first generation immigrants in the United States maintain their home language and culture or shift to the host language and culture.

It is clear that maintaining language and culture in the newly adopted country comes with its own advantages and disadvantages that can be defined in relation to the circumstances of individual immigrants, immigrant communities, and the host society. When general advantages are concerned, maintaining a native language can strengthen family bonds and reduce dissonance; that is often seen in cohesive immigrant communities where relationships between the immigrant parents and their children are strengthened (Gibbons \& Ramirez, 2004). Studies have examined how language and culture maintenance in these types of communities contribute to the making of a multicultural society, and, for example, provide the nation with competent bilingual professionals. The disadvantages for individuals, according to Gibbons \& Ramirez (2004), are that maintenance requires taking psychological risk and investing time, energy, and money. When psychological risk is present, there is usually a conflicting sense of identity. It may be inevitable for first generation immigrants to experience double identity; experiencing it may or may not be a psychologically unnerving experience. There are other issues: for example, a majority of first generation immigrants, excluding those who emigrated as children, remain distinguishable from the 
mainstream because they most often speak their L2 (second/acquired host language) with an accent.

Acculturation can be understood in various ways. Zhang (2008) notes that some scholars use the term "acculturation" and "assimilation" interchangeably. Other researchers (like La Fromboise et al., 1993; Portes and Rumbaut 2001; Schumann, 1978; and Ying, 1995) distinguish between the two terms. The second approach is the widely accepted one in the literature. According to this approach, assimilation refers to a shift from native culture to the host culture, and acculturation refers to an addition of the host culture to the native culture. Acculturation is a multidimensional phenomenon that develops gradually. In my study, I adopt the second definition. In this view, acculturation is a process of maintaining one's own culture and language and at the same time adopting the new language and new culture, while assimilation is a process of adopting the new language and culture at the expense of maintaining the home language and culture. Additionally, I take into account how Ying (1995) defines acculturation. According to her, acculturation is a product of three factors: (1) language competence (or proficiency), (2) cultural participation and (3) social network (informal social relationships). From among the three, her model gives primary importance to language competence. A study by Dutkova (2003) titled "How Czech are you really?" confirms this view. Dutkova (2003) points out that for Czechs living in Texas, the ability to use the Czech language is the key factor determining whether a person considers other people who identify themselves as Czech to be Czech. Having parents of Czech origin is not sufficient. 
Schumann (1978) presents a complex model of second language acquisition in relation to acculturation. He claims that competence in L2 (the dominant language of the broader society) is an indicator of acculturation. His model predicts that learners acquire the target language in parallel to the degree they acculturate to the target society. Schumann (1978) maintains that social and affective factors cluster into a single variable called "social distance." In his "social distance model," social, affective, personality, cognitive, and biological factors influence L2 learning. The social factors mentioned in Schumann (1978) include social dominance (or subordination) patterns, integration strategies (assimilation, acculturation and preservation), enclosure, cohesiveness and size, congruence, attitude, and intended length of residence in the new country. Dominance occurs when the L2 group is politically, culturally, technically, or economically superior to the target language group. In such situations, the members of the L2 group maintain their language and culture. Subordination of the L2 group occurs when that group perceives itself as inferior to the target language group. Subordination may or may not lead to the maintenance of the first language depending on whether its members choose to become part of the host society or to remain within the borders of their community. They can assimilate into the mainstream, adapt to the host culture, or preserve and practice their own language and culture.

Adaptation occurs when the L2 group adapts to the life style and values of the dominant group but maintains its own life style and values specific to its culture within the immigrant group. Preservation happens when the L2 group maintains its own life style and values. While assimilation creates social proximity between the two groups 
(short social distance), preservation creates considerable social distance; adaptation creates varied social distance and results in varying degrees of L2 proficiency. Enclosure represents the degree to which the L2 group and the host group share social space (for instance, in schools, churches or in the workplace). The higher the enclosure, the greater the chance that the L2 group may acquire the language of the host group. Cohesiveness and size influence intergroup contact and together they determine how well L1 may be preserved and practiced. Congruence (which is the cultural similarity between the target/host language group and the immigrant group) is also significant: the more similar the two groups are, the greater the possibility there is for social contact, which, in turn, facilitates second language learning. The L2 group's positive attitude toward the host group, and the willingness of the L2 group to stay in the area where the host group lives, also facilitate target language learning.

Affective factors mentioned in Schumann (1978) include language shock, culture shock, and motivation. Language shock refers to the tendency of an adult language learner to be afraid of being ridiculed when using a second language. The more worried the learner is about being ridiculed while using the second language, the higher the probability that he/she will continue to maintain and use L1. Culture shock, according to Schumann (1978) results in psychological disorientation; it distracts the learner from learning the target language effectively. Motivation refers to the reasons why the second language learner wants to acquire L2. Schumann (1978) follows Gardner and Lambert's (1959) model that distinguishes instrumental (goal-oriented) motivation from integrative (personal affinity) motivation. The greater the motivation to learn the target language 
and target culture, the higher the chance of acquiring them. However, if one's motivation is purely instrumental, then L2 learning occurs only to the extent one's instrumental goals are fulfilled.

Berry (2001) elaborates on the social factors presented by Schumann (1978). He constructs a framework in which he considers the acculturation strategies of the ethnocultural groups of immigrants. According to his framework, the sociocultural and political environments that exist in the adopted country condition immigrants' decisions about maintaining or rejecting their language and culture. From the immigrants' point of view, any of the following processes - integration, assimilation, separation, or marginalization - can happen. Integration happens when new immigrants maintain their first culture to some degree and at the same time participate in the society. Assimilation occurs when immigrants reject their cultural heritage and become part of the host culture. Separation occurs when immigrants hold on to their native culture and avoid interaction with members of the host culture. Lastly, marginalization happens when the immigrants show little interest in maintaining their first culture or in adapting the ways of the host society. According to Berry (2005), those who pursue the integration strategy experience less stress and adapt better than those who pursue marginalization; those who pursue assimilation and separation experience intermediate levels of stress and adaptation.

Berry (2001) highlights that the success or failure of immigrants' efforts to participate in the host culture is strictly dependant on the host society. The host society may opt for multiculturalism, "melting pot," segregation, or exclusion. The integration strategy seems to be successful only in multicultural pluralistic societies that promote and 
celebrate diversity. If assimilation is the desired goal, then "melting pot" will be the consequence. "Melting pot" is a metaphor that signifies "melting together"; the term refers to a society that attempts to homogenize by eradicating the home language and culture. When the dominant group rejects the minority group in such a manner, separation and exclusion may occur: in such situation the majority group marginalizes the minority group. In the cases of segregation and marginalization, the minority group maintains its language and culture because the group is denied access to the mainstream language and culture.

Clement (1980), Gibbons and Ramirez (2004), Schmid (2002), and others provide alternative models describing factors that influence the immigrants' maintenance of language and culture. Clement's (1980) social context model emphasizes the importance of three factors: the size of the immigrant group, the vitality of its language, and the motivation of its members in acquiring the language of the majority. Clement (1980) uses the concept of ethnolinguistic vitality to identify whether or not immigrants will maintain their language and culture in a newly adopted country. The variables constituting ethnolinguistic vitality are demography, status, and institutional support.

Later models draw on the models described above and focus on social, community, demographic, and psychological factors. Li (2006) lists socio-geographical, institutional, and familial factors that may affect heritage language maintenance. Sociogeographical factors refer to the prestige that L1 has in the eyes of its speaker community. Institutional factors include the systematic promotion of L1 by sanctioned and powerful organizations. Familial factors include the role of family and community in 
cultivating L1. Some scholars (Allard and Landry, 1994; Gibbons and Ramirez, 2004; Hamers and Blanc, 2000; Schmid, 2002) group factors that sustain bilingualism under three categories: societal factors, contact factors, and attitudinal factors. The societal factors refer to the existence of social institutions and media, and also to the prestige and the vitality of the ethnic group and its language. Contact factors refer to how cohesive and dense the immigrant community is, and also to the vitality of the language in which they prefer to conduct their social interactions within the family and larger community. Attitudinal factors refer to the psychological processes that affect immigrants' use of their native language.

Schmid (2002) lists, among other factors, various personal factors promoting first language maintenance or shift among the minority members. These factors include the immigrants' age of arrival, length of residence, gender, education, marital status, the birthplace of the spouse, prior knowledge of English, and reason for emigration. Berry (1990) claims that cultural compatibility, coping strategies employed by the acculturating individual, social support available in the new country, and experiences of prejudice and discrimination can also decide if immigrants choose to maintain their heritage language and culture.

In sum, all the factors listed above can fit into the following categories: societal factors, contact and linguistic vitality factors, community factors, attitudinal and affective factors, and personal or demographic factors. It is important to note that not all factors play a role in the maintenance of language and culture in every immigrant community. Some factors are more prominent in some communities. Some factors are not present at 
all. In the framework that follows I include the factors that may play a role in the maintenance of Polish language and culture by first generation Polish immigrants in the South Bay Area. 


\section{Chapter Two: Factors Influencing Maintenance of Language and Culture}

There are several factors that may play a role in the maintenance of native language and culture among first generation Polish immigrants living in the South Bay Area. Those factors can be arranged into four groups: community factors, demographic factors, attitudinal factors, and perceptual factors. The factors are listed below:

\section{Community factors:}

- Size of the immigrant community

- Institutions and resources available for maintenance of language and culture

2. Demographic factors:

- Length of residence

- Reason for emigration

- Marriage patterns (marital status and birthplace of the spouse)

- Gender

- Level of education

- Proficiency level in English at the time of arrival

\section{Attitudinal factors:}

- Immigrants' preferred cultural identity

- Immigrants' attitudes towards their own minority group

- Immigrants' attitudes towards the host group

\section{Perceptual factors:}

- Self-perceived status in the host society

- Self-perceived compatibility between the host and immigrant cultures 
Community factors refer primarily to the size and vitality of the minority community and the resources available for the maintenance of the immigrants' native language and culture. A well-organized community can function as a site where the minority language and culture are being maintained, providing its members with opportunities and resources for the maintenance of their ethnic language and culture. When the immigrant community is large, the members of the community are more likely to have ample opportunity to interact with other community members with whom they can use their language. Furthermore, they are more likely to meet and marry someone from the same community and possibly use the minority language at home and pass it on to their children. In addition, the size of the immigrant community often determines the degree of enclosure between the immigrant group and the host group: if the immigrants live in a broader L2 community, their level of enclosure with the host group will be lower than it is in the case of immigrants who do not live in a large L2 community.

Bigger communities usually have the necessary resources to create their own institutions and their members can cherish their language and culture through these institutions. However, if the immigrant community is very small, it may not have the necessary resources to maintain its language and culture. Institutions that support language maintenance include schools, community centers, libraries, theaters, churches, restaurants, and stores. For instance, parents send their children to minority language schools; members of the community celebrate cultural and religious events in community centers; and while participating and sharing with one another, they encourage each other 
to maintain the home language and culture. Research (Chinen and Tucker, 2006; Kim 2006; Merino, 1983; Shin, 2006; and Hayashi, 2006) generally indicates that children who do not have access to heritage language schools and other institutions are less likely to maintain their heritage language. Since a large community is more likely to provide these services and foci of social life, logically a small immigrant community (such as the Polish group living in the South Bay Area) lacks this particular factor and is therefore disadvantaged in the process of maintaining Polish language and culture. Of course, regardless of the size of the immigrant community, individual immigrants may choose different paths.

Informal structures that support language maintenance include resources such as books, DVDs, theaters, and music. These resources are accessible to immigrants if they are available in local formal institutions such as libraries or community centers. If there are no such institutions, then the immigrants have to obtain the resources independently. The influence of this factor has diminished with the widening access to and use of the Internet. Today, most people in the South Bay area (the home of Silicon Valley and the hub of developments in technology) use all kinds of communication technologies to access written, visual, audio and other types of texts in their home language and culture. Internet technology has made resources such as radio, TV, newspapers, and magazines accessible to many people. Fitzgerald et al. (2006) describe this phenomenon in Melbourne Australia where Polish immigrants use these Internet-based resources as means to maintain Polish language and culture while living in an L2 setting. 
Demographic factors influencing the maintenance of heritage language and culture include length of residence, reasons for emigrating, marriage patterns, gender, level of education, and proficiency in English prior to emigration. Length of residence can be positively correlated with a language shift towards the majority language. The longer immigrants have been living in a new country, the weaker their bonds tend to become with their mother countries. The reason why a person decides to emigrate may determine whether or not he or she will prefer to maintain the minority language in the newly adopted country. If a person is forced to emigrate (for instance, by the political situation in the home country), then he or she may hold on to his/her language and culture. In contrast, if a person emigrates voluntarily, he or she may not see much value in maintaining his or her first language.

The ethnic background of the spouse may play a crucial role in the new immigrants' maintenance of language and culture. If a person immigrates to a foreign country with a spouse, it is likely that he or she will use the first language at home and pass it to his/her children. As Fishman (1977) points out, for a language to be sustained there must be a separate domain (an area of life) where the language is used. A marriage between two immigrants who speak the same L1 creates such a domain. If a person gets married after arriving in the new country, the ethnic background of the spouse may determine whether L1 is maintained at home. If the spouse speaks the same L1, maintenance is possible; if the spouse speaks either the language of the majority or another minority language, the main language of communication at home is likely to be the language of the majority. Endogamic marriages (marriages between members of the 
same immigrant community) generally promote language maintenance, while exogamic marriages (marriages between members of two different communities, one being either the host community or another immigrant community) generally result in language shift. For example, two first generation Polish immigrants who marry are more likely to maintain their native language and culture and pass them to their children than a first generation Polish immigrant who marries a U.S.-born American or an immigrant from another country.

According to some researchers, gender can influence language maintenance. Schmid (2002) claims that it is generally the women, rather than men, who prefer to maintain their first languages in the new immigrant communities. This claim is based on the researcher's conclusion that women prefer to be nurturers and are therefore main transmitters of their culture to their children. Schmid (2002) underlines that this special role of women is true only in traditional societies where women stay at home. Polish society is traditional when gender roles are concerned; therefore it is possible that Polish women take more responsibility than Polish men for the transmission of Polish language and culture to their children.

The level of education of the immigrant community members may have various implications for the maintenance of language and culture. A high level of education of the community members may boost self-confidence and pride, and it may promote the emergence of intellectual life and the establishment of schools and other centers for language maintenance. It is more likely that educated immigrants are also more affluent, and they may have more in-depth knowledge of the formal steps that need to be taken to 
establish a school, a cultural center, or other institutions. Strong literacy skills in the native language certainly help in maintaining the minority language, but it is also possible that highly educated immigrants find fulfillment in the new society and may prefer to assimilate faster.

Whether or not immigrants know English before their arrival in the new country may influence the degree to which they may maintain their native language and culture. If at the time of arrival in the United States immigrants feel comfortable using English, then they will have an easier transition and thereby an easier time maintaining their native language and culture. In such a case, the immigrants may not even make attempts to find their native language community. In contrast, if immigrants do not know the target language at the time of arrival, in order to function efficiently in the new country, they will probably look for their minority community and strive to become part of it. As a result, some of those immigrants continue functioning in the new country without learning the host language, or they learn the host language only to the extent they need it to survive. Clearly, in these two cases there is a substantially high probability that these immigrants may maintain their L1.

Attitudinal factors refer to a person's attitudes towards his or her community, language, and culture, as well as towards the host society, its culture, and language. Those attitudes play an important role in the maintenance of native culture and language; they help to determine the degree to which immigrants wish to keep their cultural identities. Attitudes can change with time: many people may take up the lifestyle that other members of the host culture have, and they may look back at their first culture 
through critical lenses. In general, the attitudes that an immigrant has towards his/her native language and culture and towards the host society are generally the result of his/her experiences, and these experiences vary from individual to individual.

Perceptual factors refer to the way immigrants perceive their status in the host society, and to the compatibility between their culture and the host culture. Depending on how immigrants perceive the host society and their own status within it, they may employ survival strategies that push them either to maintain their language and culture or to shift towards the host language and culture (Norton, 1998). Immigrants vary in their opinions as to whether or not their groups enjoy acceptance and prestige in the society. If immigrants perceive that their status in the host society is high, then they may proudly cherish their heritage and may maintain their first language. However, if they perceive that their status in the host society is low, then they may either reject their first language as a symbol of their low status and may make attempts to assimilate, or they may feel segregated from the majority and may prefer to hold on to their language.

Another factor that may play a role in immigrants' maintenance of their first language and culture is the perception of cultural compatibility between their own group and the host group. Cultural compatibility refers to how similar the immigrant group and the mainstream group are in terms of their culture and religion. Compatibility between the immigrant culture and the host culture may lead to the acceptance of the immigrants into the larger society. Cultural incompatibility, on the other hand, may make it difficult for immigrants to adapt to the ways of the host society. If the two groups are culturally different, the host group may perceive the immigrant group as outsiders, and, as a result, 
members of the immigrant group may choose to center their lives around their first language and culture. 


\section{Chapter Three: Polish Culture in Polish Immigrant Communities in the United}

\section{States}

The United States is the major destination for Polish emigrants. It is the country with the largest Polish population outside Poland. According to data from the 2000 census, there are about 10 million people in the United States who identify themselves as Polish Americans (this community is often called "Polonia"). This is a huge number compared to the population of Poland, which is only 38 million. (Other large Polish immigrant communities in the world include: Germany [1.6 million], Brazil [1 million] and France [1 million] [About Polish Immigrants, 2002]). According to the 2000 census, American states with the largest numbers of Poles and Americans of Polish ancestry are New York, Illinois, Michigan, and Pennsylvania. Each of them is home to around one million Polish Americans. California, with over 491,000 Polish Americans, is sixth on this list; Polish immigrants constitute only about $1.5 \%$ of California's state population (U.S. Census Bureau, 2000).

The South Bay Area is centered around San Jose, California, and it includes the following cities: Campbell, Cupertino, Gilroy, Los Altos, Los Altos Hills, Los Gatos, Milpitas, Monte Sereno, Morgan Hill, Mountain View, Palo Alto, Santa Clara, Saratoga and Sunnyvale (SCC GOV, 2011). While the term "South Bay" is often used colloquially to refer to roughly the same region, Santa Clara County is the official name of the geographic region comprising these cities. According to the 2000 census data, Polish Americans constitute around 1\% of the 1.7-million population of the county, and they are the sixteenth most populous ethnic group in the county. In California, Polish 
immigrants are concentrated in Concord where they constitute $2 \%$ of the city's population (U.S. Census Bureau, 2000).

Scholars (Blejwas, 1981; Erdmans, 1995 and 1998; Kulniczak, 1978; ZanieckiLopata, 1976) agree that there have been three main waves of Polish emigration to the United States in the 20th century. The first wave of Polish immigrants came to the United States between the 1880s and the 1920s. As Kulniczak (1978) points out, the immigrants who arrived in the United States at that time were mostly peasants who were illiterate, unskilled, and Roman Catholic. Due to the fact that Poland was at that time partitioned between foreign powers and did not exist as a country, these Polish immigrants did not have a strong sense of Polish identity. The second major wave of immigrants came to the United States between 1939 and 1965. These immigrants came to the United States predominantly due to reasons associated with World War I, World War II, and their effects on the political situation in Poland. The third wave came to the United States between 1965 and 1989 during the communist regime in Poland. They left Poland mainly to escape political repression. As Erdmans (1995 and 1998) notes, the third wave of immigrants came to the United States generally for vacation or to visit family, and later many decided to stay and settle in the United States. Two informants interviewed in this study are members of the third wave of immigrants. After 1989, Polish people came to the United States for various reasons; they may be called the fourth wave. This fourth wave is most notably marked by post-communist conditions in Poland and they should be distinguished from the third communist-era wave of immigrants. People who belong to the fourth wave come from post-communist Poland. These fourth 
wave immigrants have not yet been described in the literature, but they should be distinguished from the third communist-era wave of immigrants; it is important to note that their reasons for emigrating may vary but that they do not include political reasons.

\section{Polish Language and Cultural Norms}

Polish is the official language of Poland where it is spoken widely. Polish belongs to the West Slavic family of Slavic languages; after Russian, it is the second most widely spoken Slavic language. There are a few other regional languages that are spoken in some parts of Poland, but generally Poland is linguistically, culturally, and ethnically homogeneous. Janik (1996) claims that Polish immigrants are one of the ethnic groups for whom native language and culture are core values and thus they maintain their ethnic language better than others. He adds that Greeks, Poles, Latvians, and a few other ethnic groups belong to the so-called language-centered cultures and they tend to preserve their language more often than some other ethnic groups (such as the Dutch who rapidly lose their language). Janik (1996) also cites some studies indicating that even though some ethnicities value their languages more than others, it doesn't mean that they will preserve them. He points out that Poles are not as good in language maintenance as Italians who value their language less, yet consider it as a core family value.

Norton (1998) comments on the issue of valuing language. She conducted a study comparing a Polish family and a Vietnamese family in Canada. While in the Vietnamese family subtractive bilingualism took place in the second generation (i.e., children learned L2 at the cost of L1), in the Polish family additive bilingualism flourished (i.e., children 
learned both L1 and L2). The Vietnamese family had a negative attitude towards their own minority group and made numerous attempts to fit into the larger society. The members of the Polish family, on the other hand, felt comfortable in their own native language and culture and at the same time had a positive attitude towards the host group, because they felt that their status in the society was better compared to their previous status in Austria. Advised by a Catholic priest, the parents used Polish at home and enrolled their daughter in a Sunday school. In contrast, children in the Vietnamese family didn't end up speaking Vietnamese because their mother thought that her children could potentially benefit economically from speaking English only; for this reason she did not want to speak Vietnamese with them. In addition, the same family openly considered itself and Vietnamese people to be inferior to Canadians. Eventually the Vietnamese family experienced a breakdown of relationships among themselves; they did not fully communicate with their children and they did not maintain family bonds and family values. The Polish family, on the other hand, continued to use Polish and the shared language helped preserve family bonds and Polish cultural practices.

In addition to the Polish language, a vast majority of Polish people share the Roman Catholic faith. Ever since the formation of the Polish state in 966, religion has shaped Polish culture and has dictated cultural norms. Historically, the Catholic Church has been a source of unity for the Poles; many believe that Polish national identity survived during the years of partition (1795-1918) and the communist regime (19451989) because of the unifying strength of Roman Catholicism (Parot, 1981). Many scholars (Erdmans, 1998; Galush, 1996; Radziwilowski, 1996; Zaniecki-Lopata, 1976) 
affirm Roman Catholicism's strong position in Poland as well as in the lives of Polish immigrants; Catholic missions often perform a central role in Polish communities. A large percentage of Americans is Catholic, therefore, to an extent Polish immigrants find it relatively easier to adjust. However, religion does not provide a seamless tradition. As Zaniecki-Lopata (1976) notes, Polish Catholicism is different from American Catholicism: Poles worship their own saints and Polish liturgy is a unique culturallyspecific mix of rituals and prayers; the sacraments of Confession, Baptism, First Communion, Confirmation, wedding and funeral are major milestones. Religious holidays, including Sundays, are national holidays during which most businesses are closed. Christmas and Easter are the main religious holidays and celebrating them means practicing many traditions. On December $24^{\text {th }}$, families visit each other and rejoice with a big evening meal, sharing a thin white wafer called "oplatek." On New Year's Eve, most people attend a midnight mass. During Easter, a priest blesses the meals families share that day. On All Saints' Day, Poles visit the graves of their loved ones. Children celebrate their birthdays, but most adults celebrate the day of their names, a practice that originated in the Catholic tradition of highlighting the names of saints. (Every full-size Polish calendar contains a list of name days; that helps parents to choose names for their children.) A secular but nonetheless central holiday, Women's Day, is celebrated on March $8^{\text {th }}$; that's when men bring flowers and chocolates to the important women in their lives.

There are other cultural differences between Polish and American people. Traditional Polish cuisine includes dishes such as various types of "pierogi" (Polish 
ravioli), dumplings, crepes, bigos (hunter's stew), goulash, pork cutlets with mashed potato and cucumber salad, stuffed cabbage rolls, and a variety of soups, such as sourdough soup ("Zurek" which is often cooked for Easter), red borscht (beetroot soup often cooked for Christmas) and cabbage soup (“Kapusniaczek”). Tea and beer are popular beverages. In Poland the main meal of the day is eaten in the middle of the day. During workdays the schedule gets shifted, but on weekends people eat their main meal in the middle of the day. The main meal usually consists of two dishes: the first one is a soup and the second one includes meat, potatoes or other starch, and vegetables. For other meals people commonly eat sandwiches; each sandwich normally has only one piece of bread. When visiting, Polish people are usually expected to bring gifts. It is important to be on time, exhibit good table manners, and compliment the host about the amount and quality of the food. It is the role of the host to prepare food and clean after the meal.

Polish people center their lives on their families rather than on work. Being family-oriented, Polish people draw a line between family/friends and strangers. On the street they do not look at or talk to people they don't know. Polish people can come across as very formal because the Polish language, like German or Spanish (but unlike English) distinguishes between a formal and informal form of "you." As a consequence, the formal form of you ("Pan" or "Pani") is commonly used with strangers unless they prefer to be called by their first names. Formal titles such as Medical Doctor or Professor are commonly used, and the failure to do so may result in a cultural gaffe. In spite of the fact that they pay attention to formal titles, Polish people tend to have little attachment to 
their jobs. This attitude is commonly thought to be a relic of the communist era when everybody was guaranteed a job. At that time it was common that workers didn't identify themselves with their employer (the communist government) and they did not care to get their work done. Today it is still a common attitude. However, many companies try to apply the American model where the worker is expected to show loyalty to the company.

Polish people view education differently from Americans. Generally, in Poland theoretical knowledge is highly valued while in the United States practical knowledge and skills are highly regarded. Yet when going through their primary and secondary education, Polish students are required to learn through memorizing dates and formulas. Polish people tend to think of Polish education as superior to American education. In spite of this pride, the Polish educational system has many problems. Many students do not find school subjects interesting, and they find it difficult to choose which major to pursue in college. Only a few choose mathematics or science, probably because these complex subjects are taught in a very dreary manner. In the end, because of the limited access to the most popular college departments (such as medicine, law, psychology, English, and business), many students decide to pursue other majors, many of which do not guarantee good jobs. Few can afford to pay for private colleges. As a result, many Polish people end up taking jobs with which they do not identify.

These and other traditions and national characteristics affect the degree to which immigrants in the South Bay maintain Polish language and culture. Leuner (2007) examined Polish traditions cherished among Polish immigrants in Melbourne. According to her, Polish immigrants maintain traditions such as Polish Christmas, Polish Easter and 
fasting on Christmas Eve. They celebrate Polish name days and cook Polish food. Home is the major site of language and culture maintenance, and church and school are secondary ones. The main media utilized by Polish immigrants in Melbourne are Polish television (TV Polonia) and Polish Internet. My study investigates which of these customs are being maintained by the Polish immigrants living in the South Bay Area.

\section{Resources Available for Maintaining Polish Language and Polish Culture in the South Bay Area}

The Polish Mission (full Polish name: "Polska Misja Katolicka Sw. Brata Alberta Chmielowskiego w San Jose"), located on 10250 Clayton Road in San Jose, is the main organization uniting the Polish community in the South Bay Area. It offers church services in the Polish language on Saturdays at 5:30 PM, on Sundays at 10:30 AM and 12:30 PM, and on Wednesdays and Fridays at 7:30 PM. In addition, every Sunday, one Polish family volunteers to cook a traditional Polish meal; the meal is served in the church cafeteria after the 12:30 PM mass. The church also organizes events related to Polish religious traditions such as a Christmas pageant and the blessing of foods for Easter. For the past fifteen years the church has been organizing Polish festivals that include Polish folk dances, games for children, Polish cuisine, books, and souvenirs.

The church supports the Polish Saturday School ("Polska Szkola Sobotnia"), which offers classes for various age groups. Children in kindergarten through grade 5 may attend, but children older than 11 years of age are also allowed. The school, functioning since 1986, offers classes in Polish language, literature, history, geography 
and religion. Classes are held every other Saturday from 9:00 AM to 3:00 PM. The school also runs a children's library. Other smaller and less formal organizations in San Jose include the Polish-American Social Club in Sunnyvale, the Polish American Engineers Club of Silicon Valley, and the Polonia Bay Soccer Club in San Jose.

There are a few other Polish cultural centers located in the San Francisco and Concord areas. The Concord area, home to the biggest Polish population in Northern California, has a few churches and clubs run by the members of the Polish community. The Polish community in San Francisco runs organizations such as the Church of the Nativity in San Francisco, the Polish Pastoral Mission, the Polish Club, the Polonez Soccer Club, the Chopin Foundation, and the Polish Art and Culture Foundation, as well as the Northern California Division of the Polish American Congress. (A full list of Polish institutions and clubs in the San Francisco Bay area can be found on the website www.poloniasf.org/english/organizations.php.) Since the closest Polish consulate is located in Los Angeles, churches and clubs are the main Polish institutions in the South Bay Area.

Recently, Bona Restaurant was opened in Menlo Park. During the past year Old Krakow, a Polish restaurant in San Francisco, Polish deli Seakor Deli Products (a deli in Campbell) and a Polish deli in Palo Alto closed their operations. The latter two were the only Polish stores in the South Bay. Nonetheless, Europa Deli Café in Campbell, Slavic Store in Saratoga, Winmart Russian Deli in Sunnyvale, and European Delikateski in Palo Alto are still selling Polish foods and other imported goods. All of these stores have large deli sections and they sell a variety of frozen products, sweets and pickled fruit and 
vegetables. Winmart also has a bakery that sells freshly baked pastries with sour kraut and meat that are traditionally eaten in Poland and Russia. The closest place to the South Bay where one can find Polish-only stores and restaurants is in Concord, which is located in the eastern San Francisco Bay Area.

There is no Polish library in the South Bay Area (or in the whole of the Bay area); however, the biggest public libraries in the South Bay Area have some collections in the Polish language. Dr. Martin Luther King Jr. Library in San Jose has 441 items in the Polish language, including fiction, history books, and DVDs. Santa Clara County Library has 119 items related to or in the Polish language. These include a few Polish DVDs, books for children, and a few contemporary Polish works of fiction translated into English. And, the Saturday and Sunday schools run by Polish churches also have children's books and other materials in Polish.

The Internet offers endless resources in Polish language. Polish television, TV Polonia, can be streamed online on the website www.tvpolonia.com. Polish radios can be streamed on the website www.radiostacje.com. Websites, such as www.capolonia.com and www.poloniasf.org, serve as sources of information for news about Poland and Polish events in California and the San Francisco Bay Area. There are also a number of web pages directly addressed to Poles in the United States. The website www.polonia.net provides general information about Polish institutions and events in the United States; the website www.capolonia.com is specifically addressed to Poles in California; and the website www.poloniasf.org is addressed to Poles in the Bay Area. The website www.polishdating.us specializes in providing online dating services. Clearly, given that 
there are almost half a million Polish people living in the Bay Area, there are very few resources and relatively few opportunities for Polish immigrants to maintain their Polish language and culture. 


\section{Chapter Four: Methodology and Findings}

\section{Informants}

Six first-generation Polish immigrants were interviewed in this study. Four of them are women and two are men. All came to the United States as adults. Two have been living in the United States for longer than 20 years, two for 11-20 years, and two for 10 years or less. Of the six, two are married to other first-generation Polish immigrants; one to a second-generation Polish immigrant; one to an Anglo-American man; and one to an immigrant from another country (India); one is unmarried. The following table provides information about the informants:

Table 1: Informants in the study

\begin{tabular}{|l|l|l|l|}
\hline $\begin{array}{l}\text { Name and } \\
\text { gender }\end{array}$ & Age & Married to & $\begin{array}{l}\text { Length of stay in } \\
\text { the U.S. }\end{array}$ \\
\hline Alina (f) & 55 years old or over & $\begin{array}{l}1^{\text {st }} \text { gen. Polish } \\
\text { immigrant }\end{array}$ & More than 30 years \\
\hline Arek (m) & $41-54$ years old & $\begin{array}{l}1^{\text {st }} \text { gen. Polish } \\
\text { immigrant }\end{array}$ & $21-30$ years \\
\hline Agnieszka (f) & $35-40$ years old & American & $11-20$ years \\
\hline Monika (f) & $29-34$ years old & $\begin{array}{l}2^{\text {nd }} \text { gen. Polish } \\
\text { immigrant }\end{array}$ & $11-20$ years \\
\hline Kasia (f) & $35-40$ years old & Other immigrant & $7-10$ years \\
\hline Dariusz (m) & $29-34$ years old & Unmarried & $7-10$ years \\
\hline
\end{tabular}




\section{Research Questions}

The following research questions govern this study:

1. To what extent is Polish language practiced by the first generation Polish immigrants?

2. To what extent is Polish culture maintained by the first generation Polish immigrants?

3. To what extent is Polish language passed onto the second generation?

4. What specific variables influence the language/culture maintenance in the first generation Polish immigrants?

\section{Data Collection}

Data were collected by conducting one-on-one interviews with the informants and by administering a questionnaire. (The nine interview questions are listed in Appendix A.) The questions asked the informants about the circumstances of their coming to the United States and the role of Polish language and culture in their lives. The informants were also asked about their participation in Polish community activities held in the Bay area, about their attitudes towards Poles and Americans, and about the Polish language and cultural resources that they use. The questionnaire (included in Appendix B) consisted of 57 questions. The questionnaire was designed to elicit personal information as well as detailed information about the subjects' use of resources that help them maintain their Polish language and culture.

In order to identify informants for this study, I used e-mail to contact potential informants whom I knew and others that were recommended by my non-Polish acquaintances. I chose informants who were from various age groups and involved in 
different marriage patterns. Out of 16 people contacted, 13 responded, and six agreed to participate in the study. The informants were free to choose a meeting time and place that was convenient for them. Six interviews were conducted. All interviews and administering of the questionnaire were conducted in Polish. Interviews were audiorecorded using an iPhone and they were later summarized in English. The summaries were sent to the interviewees together with a letter asking them to confirm the accuracy of the information.

In the questionnaire each informant was required to provide information regarding his/her gender, age at the time of arrival in the United States, length of residence in the United States, reason for emigrating, and level of education accomplished at the time of arrival in the United States. There were also questions regarding the informants' use of the Polish language, participation in Polish community-related events and activities, and observance of Polish customs and holidays.

\section{Findings Regarding Individual Informants}

This section summarizes the information collected from interviews and questionnaires about individual informants. Each informant has been assigned a pseudonym. Information about each informant is summarized with regard to the following topics:

1. Circumstances of coming to the U.S.

2. Maintenance of Polish language and culture at home

3. Participation in the Polish community 
4. Contact with Polish family and friends in Poland and in the U.S.

5. Attitudes towards other Poles and Polish culture

6. Attitudes towards Americans and American culture

7. Perception of compatibility between Polish and American cultures

8. Perceived self-identity

Alina (female, about 32 years in the U.S.). Alina is in her early sixties and she has lived in the United States for 32 years. She left Poland during the communist era. She is married to another 1 st generation Polish immigrant whom she met after coming to the United States; they have two sons who speak Polish fluently. Overall, Alina maintains Polish language and culture at home and is passing them onto her children. Her home is full of Polish language books and DVDs. Polish radio is often heard in her home. In addition, Alina has showed some leadership in the community by teaching in a Polish school.

Alina emigrated to the United States at the end of 1970s. In Poland she lived in a big city (Warsaw) and worked as a stewardess, travelling all around the world. Her parents were well-educated and Alina, living in the capital, had a better life than she would have had if she had lived anywhere else in Poland. Due to her job, her lifestyle was different from the lifestyles of other Poles: as a stewardess, she could shop in special stores where she could buy anything she wanted; other Poles, on the other hand, had to shop in regular stores which were almost always empty. It was only when she became pregnant that Alina started experiencing the harsh reality of the communist regime: she 
was not working as a stewardess anymore and she realized that "it was almost impossible to buy food and other necessities in Polish stores." Not being a member of the communist party, Alina experienced some political repression in communist Poland. (When she was employed, she was constantly threatened that she would get fired unless she joined the communist party.) Yet this repression did not motivate her to leave the country. Alina's primary reason for emigrating was that her 3-year-old son fell sick and a doctor recommended that the family move to a place with a warmer climate. Alina applied for a visa to spend some time at her friend's house in the United States. Once she left Poland, she considered the possibility of settling in the United States; however, she did not have a clear intention to never go back to her home country. In the United States she met her husband, another immigrant from Poland whom she married and with whom she has a second son.

Since her husband is also Polish, for 32 years Alina has been speaking Polish and actively maintaining Polish culture in her home. She often cooks Polish food because her husband and sons enjoy eating it. Alina keeps herself updated about Polish political events on a weekly basis. She listens to Polish radio every day, reads an online newspaper, "Zycie Warszawy," once or twice a week, and watches Polish television online at least once a month. She buys Polish DVDs and watches them with her family. Christmas and Easter are major holidays in her house and the family always celebrates according to Polish tradition. She and her family celebrate American and Polish holidays that are common for both cultures but they are celebrated following Polish traditions. For 
instance, during Christmas her family always has a feast on the $24^{\text {th, }}$ and not on the $25^{\text {th }}$ of December.

Alina always considered Polish language a part of her Polish identity; for that reason she wanted her children to speak Polish, so that "they could feel that they were Polish." Also, she wanted her sons to be able to communicate with their grandparents, cousins, and other family and friends in Poland. When a part time Polish school was in operation for a while in Cupertino, Alina enrolled her sons in the classes offered in that school. The classes were held six hours a week during weekday afternoons. Later, Alina herself became a teacher in that school. She became very dedicated to teaching Polish history and literature, although it was frustrating for her to see that many parents didn't take the school seriously: "they treated it as a place where they could leave the children for free and go shopping. I was stunned hearing that the parents as they were picking up their children were speaking English to them." Both of her sons were baptized in the Catholic Church and spoke Polish before they spoke English. Now her sons have grown up and have moved away from their parents' house, but Alina plans to actively participate in the upbringing of her grandchildren so that they too learn Polish and grow up with Polish traditions. Both sons are married to American women and Alina is aware that unless she takes charge of her grandchildren's upbringing, they may never learn to speak Polish.

It is hard for Alina to say whether or not she is part of the Polish community. The Polish community in the South Bay Area is quite small. In addition, the long commute between Alina's house and the Polish church prevents her from attending church 
regularly. She used to go to another Polish church quite often since it was nearby, but the church was shut down. Now she attends the Polish church only during Christmas and Easter. Alina often works on Sundays. For this reason, she has never been an active member of the Polish parish or any particular group, Polish or American. Alina used to attend Polish events such as concerts by Polish bands. In her opinion, there are very few Polish events available nowadays and "those that are offered are not always interesting."

Alina knows many Polish people in the area and some of them are her close friends. She, however, claims that she does not choose her friends based on their cultural affiliation and nationality. A majority of her closest friends are not Polish. Alina helped a few family members to immigrate to the United States and she continues to maintain contact with all of them. In addition, she maintains frequent contact with a few of her friends who still live in Poland. However, due to lack of time, she has visited Poland only five times since she left the country for good; she and her husband started their own business and it has become impossible for them to take any vacation, especially one that requires leaving the United States for an extended amount of time. To compensate for that, Alina makes sure that her sons visit Poland every year.

In general, Alina has a positive opinion about Polish people, although she admits that they have some characteristics that she dislikes. For instance, she knows a few Polish people in the area who "always complain about everything," and she sees complaining as a typical Polish characteristic. In Alina's opinion, "any new immigrant should adjust to the ways of life in his or her new country." Alina finds it inappropriate that these Polish people constantly complain about their lives in the United States in spite 
of the fact that they have chosen to live here. However, in her opinion, not all Poles in the United States or California are the same and "who they are now depends on what they were like before they came to the United States." Alina notes that her level of identification with other Polish Americans did not influence her decision to maintain Polish language and culture. Alina maintains Polish language and culture because she wanted her children to "grow up the way I did and speak the same language as I speak." It was her personal sense of Polish identity that was a decisive factor.

Alina has a positive attitude towards Americans. In her opinion, it is necessary for an immigrant to respect the host community. She considers herself American since she has spent more than half of her life in the United States. She has strong admiration for Americans' positive attitude toward work. While living in the United States, she has become very appreciative of hard work: she was employed full time while she was raising her children. In Alina's opinion, her lifestyle and values somewhat differ from American values because of her Polish upbringing. Alina personally does not like Americans being "consumption-oriented" because she herself spends money wisely. She rarely eats out; eating at home is her "typical Polish habit." She does not like fast food, sodas, or frozen meals; she considers American food unhealthy. In addition, education is very important to her and she is proud of her Polish education, which she finds to be superior to American education. Also, Alina prefers to "eat in our way with a knife and fork," not with a fork by itself, the way it is customary in the United States. In spite of all these differences, she feels that Polish and American cultures are not incompatible. 
Alina identifies herself as Polish rather than American, although she also states, "I am American. I have American citizenship and I have chosen to spend my life here." She is comfortable being both Polish and American and she doesn't think that she has to choose between the two identities. She prefers to speak Polish rather than English, although she admits that sometimes she has trouble finding the right words in both languages:

Polish is my native language and, since I keep on using it in my everyday life, I prefer it to English. I don't think that my proficiency in Polish has decreased. On the other hand, I live in California, which is essentially English language mentality. Some words that we use here in English just don't have equivalents in Polish or it takes some thinking to translate certain words into Polish. As a result, I sometimes use English words when I speak Polish but I know that I would have the same problem if I were in Poland and tried to explain certain Polish things in English.

Arek (male, about 25 years in the U.S.). Arek, now in his mid-fifties, came to the United States 25 years ago together with his wife. They continue to speak Polish in their home and their children also speak Polish. Arek notes that his wife should get full credit for it. Overall, Arek and his wife maintain Polish language and culture at home, and they are passing Polish language and culture to their children, but they do not participate in Polish cultural activities frequently. Arek also admits that he does not keep in touch with Polish friends in the area or back in Poland. Arek came to the United States as a refugee forced out by the Polish communist regime. He left Poland in the 1980s. After staying in Western Europe for a few months, he managed to come to New York and apply for refugee status. He learned English in Italy prior to coming to America. He 
came with a few other Polish immigrants and they helped each other. His wife joined him later. In Poland he had a college degree and was working as an electrical engineer, but life there was difficult for him: basic commodities were hard to obtain and freedom of speech was limited.

Since Arek's wife is Polish, Polish has been the main language used in their home. Major Polish holidays, such as Christmas and Easter have been celebrated in their house throughout the years. They also celebrate a few other traditional Polish holidays such as All Saint's Day (the day when Polish people visit the graves of their dead family members). After their children were born, some other Polish traditions, such as "Smigus Dyngus" (celebrated on Easter Monday when children spray each other with water) and "Prima Aprilis" (celebrated on April $1^{\text {st }}$ when children try to trick each other), were revived in their house. Arek's family sometimes watches Polish films and listens to Polish radio. They stay updated on current news about the political situation in Poland. Arek's wife makes Polish meals every weekend and sometimes during weekdays as well. In Arek's opinion, the fact that both he and his wife are Polish has enabled them to maintain Polish language and culture in their house; specifically, it is due to his wife's effort that they are able to raise their children as "Polish," and that their children know Polish language, history and customs. Arek's children participated in traditional Catholic ceremonies such as baptism and first communion, and they attended some Polish classes too. Arek uses Polish more frequently than English in his daily life. However, he admits that although his children speak Polish fluently, he sometimes communicates with them in English. Arek describes the situation as follows: 
They start speaking to me in English so I answer in English. I always start a conversation in Polish but they still sometimes answer in English. Then we have a Polish-English exchange, because I stubbornly stick to Polish and they stick to English. I guess that means that they are more comfortable using English and I'm more comfortable using Polish.

Arek practices Polish culture, although he admits that he doesn't "go out of his way to participate or to show leadership in the Polish community." In Arek's opinion, "if a person really wants to participate in the community, he or she will find opportunities to do so." He admits that he never had time or enough interest to regularly participate in Polish events, even though he is aware of the existence of Polish churches and cultural centers in San Jose, San Francisco and other cities. Nevertheless, with his family he celebrates major Polish holidays, visits a Polish church twice a year, eats in Polish restaurants, and shops in Slavic stores. When the family lived in the Eastern Bay area, they used to "do more Polish activities." Back then, Arek's daughter attended a part-time Polish school and participated in a Polish dance group.

Even though Arek deeply identifies himself with his Polish heritage, he says that he never chooses his friends based on their nationality. A majority of Arek's friends are not Polish and the few Polish immigrants in the area who are his family's friends are professionals and they lead a middle-class lifestyle similar to Arek's. Arek notes that Polish immigrants are not a homogeneous group:

The time when the person came to the United States really matters. If someone moved to the U.S. recently, that person will have very little in common with us who emigrated more than 25 years ago. Also, they will probably belong to a different age group. 
Arek visits his homeland every three or four years, although his wife, who is a middle school teacher, goes to Poland every year. They also keep in touch with their friends in Poland. Arek admits that after more than 20 years it is simply impossible to maintain close contact with friends who live in a totally different reality:

After a few years you don't have anything to talk about because you don't share any common experiences. Same with following politics: you may understand a little bit, but you're not there so even though you know the names of the president, prime minister and the ruling parties, you can only understand so much.

Arek is proud of being Polish. He knows some Polish immigrants who during the last decade entered the United States on temporary visas, such as "work and travel," and never left; thus he believes that many Polish immigrants in the United States are staying in the country illegally. To Arek it does not matter whether a person is legally or illegally staying in the United States. "I respect anyone who works hard," he said. Arek does not hold any negative feelings towards Poland or Polish people. He shares an interesting observation:

Like many immigrants, I became nostalgic. I have this weird pride about being Polish, and even though I don't necessarily have the highest opinion about Polish people, I will keep all the negatives to myself and always speak positively about Poland, Polish people or Polish immigrants, at least when I speak to non-Polish people. But then, there are things that I don't like, like the endless complaining.

Arek has a positive attitude towards Americans; those whom he has met at work or in the community are always respectful of his Polish roots and they appreciate his hard work; he has been told many times that Polish people have great work ethics. He has 
seen some Polish people cherishing negative attitudes towards Americans, but in Arek's opinion that negativity comes from a "sense of inferiority." In contrast to these people, Arek is generally happy with his lifestyle in the United States.

In Arek's view, Polish and American cultures are compatible. He reports that coming to the United States from communist Poland was a big cultural shock for him, but that the differences between the two countries and their cultures were easy for him to reconcile. In Arek's perception, Poland has drastically changed during the last 20 years and "it is heading towards where the U.S. is now." Arek claims that "young people who now move to the U.S. from Poland don't encounter as many differences as I did.” Arek admits that one thing that was difficult for him to get used to in the United States was calling people by their first names rather than by their last names preceded by a polite Mr. or Mrs. However, after he got used to the American way, Arek finds it difficult to switch back to using the polite forms in Polish. Likewise, he got accustomed to smiling at people on the street and saying "hi" to strangers - things that he would never do in Poland. Now each time he goes back to Poland he is surprised that "nobody smiles or makes eye contact on the street." Arek sees himself as both Polish and American. When he and his family go to Poland, they speak Polish and they "do not feel as outsiders," except that "only sometimes a word in English would slip out and all of us would go 'whoops."

Arek regards American work ethics very highly. According to him, the United States is "a land of opportunities for entrepreneurs." In contrast, during communism in Poland, innovation was impossible and the political reality did not create prospects for 
jobs. Also, people did not work hard because communism did not enforce outcomes. In the United States he feels productive and through a high salary he gets sufficiently rewarded for his work. Overall he considers his life style in the United States to be better than the life style that he would otherwise have in Poland.

Agnieszka (female, about 12 years in the U.S.). Agnieszka, a 33-year-old woman, came to the United States 12 years ago. She is married to an American man; their two children do not speak Polish. Overall, Agnieszka does not maintain Polish language and culture. She does not use Polish language at home or have close Polish friends in the Bay Area. Neither does she attend Polish community events.

Agnieszka came to the United States right after she completed her bachelor's degree in Poland. Initially she planned to spend only one year in the United States. She came on a "work and travel" program; she wanted to travel and explore "different possibilities outside Poland." Later she decided to stay in the United States, get married, and pursue her MBA. Marriage was the reason she decided to settle down in the United States. In the United States Agnieszka did not seek the company of other Polish people, because her English was good enough to communicate with anyone.

In her everyday life Agnieszka hardly ever speaks Polish. Her husband is American and her children speak English only. It has occurred to her that she should speak Polish with her children so that they can communicate with the Polish side of the family but she finds it difficult to teach them Polish when English is the language spoken at home. Agnieszka works full time, and when she and her husband come back from 
work they speak English; there are, therefore, few opportunities for Agnieszka to speak Polish with her children without leaving out her husband. Baptizing her children was one way in which she followed Polish traditions; however, this happened partly because her husband is also a Christian.

Agnieszka visits Poland only sporadically. She has become very close to her husband's family; she always celebrates major American holidays with them. Even before she married, she celebrated American holidays more often than the Polish ones, because it was during the American holidays that she had time off and because she did not have Polish friends with whom to celebrate them. Agnieszka shared her reflection as follows:

I would forget about Easter and only find out from my parents that they celebrated it a week before. Nobody here celebrates the holidays that are traditionally acknowledged in Poland so I typically work on those days. Also, the fun is in sharing, spending these holidays with family and friends. If people around me don't celebrate them, then why would I?

Similarly, Agnieszka does not cook Polish food because traditional Polish meals take a lot of time to prepare; in contrast, American food is easily available and faster to make. She admits that she left Poland before she had a chance to learn how to cook well and before she "developed lifelong habits": "I came when I was young enough to still be able to adjust to whatever life brought." Agnieszka claims that she knows about a Polish church in San Jose and a Polish community center in San Francisco, but she has never visited either of the two. She believes that these Polish community groups are very small and that they primarily attract Poles who live nearby. When she worked for an au pair 
company, Agnieszka came across a few Polish au pairs, but she did not "connect" with them since these girls were new in the United States.

Agnieszka says that she keeps in touch with her family in Poland mainly through Skype and with a few friends mainly through Facebook; however, with time these connections are growing weaker. She is close to her sister with whom she often talks on the phone or via Skype. She and her husband met a few Poles in the area who do not have a close connection with the Polish community. As she admitted, her husband actually knows more Polish people than she does. Agnieszka does not miss the lifestyle that she had in Poland. In fact, she disliked many aspects of her life there:

I always used to take a bus and it took forever to get anywhere. After you took one or two buses, you still had to walk. If you went to get something done in the city council, you had to take a day off work or school because you didn't know how much time it would take you to get the thing done. If you went to the university library, it took a whole afternoon because you had to get there first. Basically, you could do one errand per day.

Agnieszka says that she dislikes the fact that "little things take forever in Poland." She also dislikes that Polish people are often unpleasant to each other - especially when there is a hierarchical relationship between them. In Agnieszka's experience, in Poland "people exercise their power whenever they can and you can see it right away when you get off the plane and at the airport nobody is nice or helpful to you." In addition, Agnieszka finds Polish complaining unbearable. In her opinion, people should take charge of their lives, but she believes that many Polish people fail to do so; instead, they prefer to complain. 
Agnieszka appreciates that Americans always project a positive image: they smile at each other on the street and are polite to each other. In her opinion, Polish people can improve their lives by learning a few things from Americans. Agnieszka mentions that when she visited Poland for the first time after many years, she realized that she was "no longer in the United States because people stared in the ground; they did not smile at each other and say 'hi' the way they do in the U.S." In her opinion, "Polish people should learn to be optimistic. If you look at them walking down the street, you would think that they are martyrs." Similarly, Agnieszka values American self-confidence and she thinks that Polish people could be more like Americans in that regard. She likes Amercian education. In her opinion, American teachers "do a great job educating students who are self-confident critical thinkers while Polish teachers always try to bring students down and cut their wings."

Agnieszka did not find it difficult to get used to the American life style. With time she has become so accustomed to life in California that she forgot that she "ever lived anywhere else." She reflected as follows:

In the beginning [of my stay in the United States] everything seemed strange; especially the food did not taste good. But with time I got used to everything. It's hard to believe it but now when I look back at my life in Poland I see faults while in the beginning I would only see faults in the American way of life. The same with food, I got used to the American food, which used to taste too sweet and salty in the beginning; now Polish food tastes bland.

One thing that Agnieszka grew up doing and that she still practices is that she "cannot leave the house in pajamas." In Poland it is customary to wear different clothes at home and outside of the house; Agnieszka still divides the clothes in her closet into two groups: 
one group with the clothes that she wears outside the house, and the second group with worn-out clothes that she wears at home. In spite of the fact that she does not have much connection with her home country, Agnieszka still identifies herself as Polish. At the same time, she is an American citizen, and so she identifies herself as American as well. As she reflects, she is starting to feel like the second generation Poles who claim that someone in their family was Polish. In her own words, the reality is that she is "very American."

Monika (female, about 11 years in the U.S.). Monika, a 31-year-old woman, came to the United States eleven years ago, right after she graduated from college. She is married to a second-generation Polish man. Since her husband speaks very little Polish, she and her husband do not use Polish at home; however, Monika often speaks Polish with her daughter. In addition, she frequently visits her in-laws who live nearby; the family celebrates major Polish holidays in their house. Overall, Monika maintains Polish language and culture at home, and she has made it her goal to pass Polish language and culture to her children. She has many Polish friends in the area and she regularly contacts her family and friends in Poland.

When Monika came to the United States, she did not have the intention to settle in the United States; at first she only planned to live in California for a year, working and traveling. Her reason for staying was that she fell in love with a Polish man. The relationship did not last, but with time Monika got used to living in California and she did not want to go back to Poland even though her visa had already expired. She kept living 
in California for another four years until she met her current husband, a secondgeneration Polish man. Once they were married, she was able to go back to school and obtain her MS degree. Now Monika has a daughter and she is expecting another child.

It is very important for Monika that she maintain her native language and culture at home. She exclusively uses Polish to communicate with her daughter. When the girl is older, Monika wants her to attend Sunday school in the Polish church. For now, the girl watches Polish cartoons and soon she will learn to read Polish; Monika's mother brought a lot of Polish books for her granddaughter when she came to visit. Monika's husband speaks very little Polish, but he still tries his best to speak Polish with their daughter. Monika and her husband speak English to each other, so English ends up being the main language spoken at their home. However, Monika still uses Polish frequently. In her opinion, she is still as fluent in Polish as she used to be when she lived in Poland. Monika frequently celebrates Polish holidays; for instance, last April during Easter she took her daughter to bless foods at the Polish church. Monika and her first generation Polish mother-in-law often organize family gatherings for Christmas and Easter. Unfortunately, once the rest of the family joins, English becomes the main language spoken. Monika frequently visits Slavic stores in the area in order to purchase Polish food and magazines. She reads Polish books and magazines, and watches Polish films and TV Polonia online. The only TV show that her daughter is allowed to watch is a Polish cartoon screened on TV Polonia called "Koziolek Matolek."

Monika doesn't consider herself as a part of the Polish community in the South Bay Area. In her opinion, even though there are many Polish people in the area, the 
Polish community is not well organized. She points out that for some reason Polish people, unlike some other members of European minorities in the area, “don't act together in order to create some meaningful structures" of cultural maintenance. According to Monika, Polish immigrants do not show leadership in the community and "without the leaders who initiate community events, clubs, and institutions, nothing will ever change in the Polish community." Twice a year Monika visits the Polish church in San Jose; she would be willing to go there every week if the church were closer to her home. However, in her opinion, "church is not enough to keep a Polish community together" because many Polish immigrants in the United States have moved away from religion. Monika has a few good Polish friends with whom she speaks Polish on a weekly basis. In addition, she speaks Polish with her mother-in-law who lives nearby and with her mother with whom she talks on the phone for a few hours a week.

Monika gets along well with a majority of Poles. She enjoys exchanging recipes with her Polish girlfriends and having other Polish families over for dinner. On the other hand, she dislikes a big number of the Polish people whom she has met in the Bay area because, she says, they are alcoholics. Monika's father was one too. Her husband is an exact opposite of these men: he never drinks and he cares for his family. In Monika's opinion, in this regard he is more like American men and she appreciates that. Monika likes the fact that Polish people are very family-oriented. A low rate of divorce, in Monika's opinion, is a reflection of the fact that Polish people are deeply devoted to their families. In addition, Monika finds Polish people to be very hospitable. For instance, according to her, the idea of a potluck does not exist in Poland; there, it is the 
responsibility of the host to provide the guests with food and drinks. Monika gets along well with Americans. She also enjoys her lifestyle in California. Hers and her husband's income allows them to live a better life than she would ever have in Poland. She stated that in Poland she could never afford a house and two brand new cars.

In Monika's opinion, her lifestyle slightly differs from the normal American lifestyle. For instance, Monika cooks her meals rather than buys them pre-prepared. Like many Polish women, she feels that as a woman she is responsible for house chores and cooking. However, after her daughter was born, Monika (influenced by American values) preferred asking her husband for more help in house chores. Also, in Poland children often live with their parents after they get married, because it is difficult to find affordable housing. As a result, it is common to find three generations of family living together. Monika, used to this model, would like her mother to move to the United States and live in her house.

Overall, Monika does not see her life as different from her neighbors' lives. She is aware that in Poland she used to do certain things just because other people do them. In California, she does not celebrate some of the holidays that are commonly celebrated in Poland because they are not celebrated in the United States. Monika describes culture maintenance as a very simple phenomenon:

People do certain things because others around them do them. For instance, during Easter in Poland everybody cleans their houses, bakes cakes, and does a lot of grocery shopping. So you do all of it as well; you talk to your friends about it and you hear about it on TV. Why would I celebrate "Andrzejki" [a Polish holiday] here if nobody else around me does? 
Monika suggested that for her the maintenance of home culture depends on the "support network" of other people around her, preferably other Polish immigrants who celebrate Polish holidays together with her. She describes herself as Polish rather than American. She says: "Of course, I feel more Polish, I was born in Poland and not in the United States." On the other hand, she admits that she happily accepts some American values and customs.

Kasia (female, about 8 years in the U.S.). Kasia, a 33-year-old woman, came to the United States eight years ago. She is married to a recent immigrant from India; their 5-year-old daughter does not speak Polish. Overall, Kasia describes herself as a person who does not go out of her way to maintain Polish culture. She admits that she rarely uses Polish. For six years after coming to the United States she was not interested in getting to know other Polish immigrants in the area. It was only recently that, thanks to a randomly encountered Polish-Indian group, she began to spend time in the company of other Polish women married to Indian men.

Kasia came to the United States after she finished her Master's degree in Poland. She was working for an international student association in Poland; she left the country to work, travel, and experience other cultures. She lived in the Dominican Republic for a year and then in California for another year. She was planning to return home after her contract ended, but she decided to stay in the United States when she met her future husband whom she married within seven months of their first meeting. Before she met him, she was sure that she would live the rest of her life in Poland and marry a Polish 
man. At the time of this interview she is married, has a five-year old daughter, and is expecting another child.

After she came to California, Kasia did not seek the company of other Polish people. Until recently she did not know any Polish people in the area; neither did she attend any Polish events. In her opinion: "it's not enjoyable to attend events that you remember being majestic in Poland while here they are very small." Once she became a mother, Kasia realized that her children should learn Polish language and culture. She wanted her daughter to be exposed to Polish traditions. Also, Kasia wanted her children to speak Polish but, considering that her husband does not speak Polish and that the main language spoken at home is English, it is difficult to achieve that goal. Kasia originally intended to speak Polish with her daughter. However, her daughter had many health problems and she ended up speaking much later than other children. Kasia and her husband were afraid that their daughter might be developing slower than other children, and therefore they focused on teaching her English only rather than Polish or Bengali along with English. Later Kasia contacted the Polish church in East San Jose where she wanted her daughter to attend Polish classes. Unfortunately, it turned out that the school offered classes only for children who already knew some Polish. Kasia hopes that their second child will learn to speak Polish and Bengali and that their older daughter will then become interested in learning both. Kasia said that her daughter could already understand simple commands in Polish, such as "tie your shoe" or "come here." Kasia also hopes that when her children are older they will spend more time in Poland where they can practice speaking Polish. It is important for Kasia and her husband that their 
children learn their parents' native languages in order to be able to communicate with grandparents, cousins and other family members. Kasia and her husband do not plan to raise their children in a particular religion although they want their children to understand both Catholicism and Hinduism. Because of her daughter, Kasia celebrates all major Polish holidays: she also celebrates North Indian and American holidays.

Kasia travels to Poland every three years. Usually one summer the whole family travels to Poland, next summer to India, and another year somewhere where they have not been before. Through her family and online news websites, she stays updated about news in Poland. Kasia knows that it is possible to watch Polish TV and listen to the radio through the Internet but she does not have time or desire to use these resources.

Kasia admits that she does not cook Polish food very often because it is too elaborate and it takes a lot of time to prepare. She has learned how to cook Indian food from her husband and mother-in-law, and she makes Indian food on a daily basis. When she became pregnant with her second child, she hired an Indian woman to cook for the family.

Kasia does not usually participate in Polish cultural events because there are very few of them; also, her husband doesn't speak Polish. After her daughter was born, Kasia started taking her to the Polish church in San Jose at least twice a year. Until recently Kasia had no Polish friends or acquaintances in the area, but a few weeks before I interviewed her she met another Polish-Indian couple who are a part of an organized group of Polish-Indian couples in the area. Through that group, Kasia met other couples of Polish women married to Indian men. They get together frequently: they watch Polish 
and Indian films, go out, or cook Polish and Indian food. Except for the members of the Polish-Indian group, Kasia knows only a few other Polish people in the South Bay Area; a majority of her friends are American or Indian. She lives in an Indian neighborhood and she perceives herself as belonging to an Indian community rather than a Polish or American community. She rarely speaks Polish in her everyday life, typically only when she speaks to her mother on the phone.

Kasia has a positive attitude towards Polish people. She does not see any significant differences between Polish people and people of other ethnicities, or between living in Poland and living in California. She admits that she could move to Poland anytime, although she is aware that it would be difficult for her daughter and husband to fit into the white population in Poland and withstand the racism of Polish society. Kasia has positive attitudes towards Americans. Even though her husband refused to apply for American citizenship, she did. The only thing that she dislikes about the United States is its primary and secondary education system. She is concerned that her children may not receive good education in American schools.

Kasia sees Polish and American cultures as compatible, although she notes that Polish and Indian cultures are even more compatible because they both value family. Kasia considers herself primarily Polish, although she has both Polish and American citizenships and she plans to continue living in the United States. She and her husband own a house and they are not planning to move away from the area but Kasia does not think that she is leading a better life in the United States than what she would lead in Poland. In her opinion, 
It's a trade-off. In Poland people have lower salaries and smaller houses or apartments, but, on the other hand, they work less, have longer vacation, get free healthcare and have a relatively stress-free life. In California I may have a nicer house or a car than I would have in Poland, but I also work a lot more, have only seven days of vacation, and I have to pay a lot of money if I get sick, or even just in regular bills.

Dariusz (male, about 7 years in the U.S.). Dariusz, a 30-year-old man, has been living in the United States for seven years now. He is single. Even though he identifies himself as Polish, Dariusz does not use the Polish language or practice Polish culture. $\mathrm{He}$ does not have any Polish friends and he does not see the need to join any Polish community. Dariusz came to the United States to pursue his doctorate in engineering. He chose to study outside of Poland because he considered American education superior to European education. Also, he wanted to "explore opportunities that the world offered him." After finishing his degree, he started working for a high tech company. He is not an American citizen yet, but he intends to stay in the United States and apply for citizenship shortly. He knew English very well when he first came to the United States; because of that, he did not seek the company of other Polish people and till date he does not have any Polish friends in the area. All of his friends are either Americans or foreigners from countries other than Poland.

Dariusz admits that after coming to the United States he "lost touch with the Polish roots." He does not belong to any local Polish community and he rarely speaks Polish. He never eats Polish food, watches Polish TV, or listens to Polish radio. He admits that since his English is "near-native," it does not make a difference to him 
whether all of these activities are performed in Polish or English. Media in English are widely available and so he does not see the point of going out of his way just to obtain Polish sources. Similarly, he cooks simple food or buys ready-made meals: since Polish meals involve elaborate cooking and because it is hard to find the ingredients in the stores, he prefers American dishes. If he gets married and has children, he will not teach his children Polish. According to him, the Polish language is not very useful because it is spoken only in Poland. He would prefer that his children learn Mandarin because it might help them in their careers. When asked whether there is any cultural value in maintaining Polish, he answers that he is not planning to travel to Poland often and so his children, if he has any, will have very few opportunities to ever use Polish even if they learned it.

Dariusz is not familiar with any organized Polish community in the area and he does not have any interest in finding out more about it. When he lived in Stanford, he had an impression of being part of an international student community. He perceives his work environment as multicultural rather than primarily American. Dariusz does not have Polish friends and he does not speak Polish in his everyday life. Occasionally he talks to his parents who live in Poland. Marrying a Polish woman is not important for Dariusz. His former girlfriend was a Chinese American woman; Dariusz claims that he is interested in dating women who are not Polish.

In Dariusz's opinion, Polish people are "somewhat racist" because Poland is a very homogeneous country. He appreciates the fact that the inhabitants of the South Bay area are tolerant when it comes to race and skin color. In addition, Dariusz does not like 
the fact that Polish people "always complain instead of taking charge of their lives." Dariusz reports that "when two Polish people get together they always start their conversation with everything that is going wrong in their lives and they find it inappropriate to say anything positive so it is always an exchange of negatives." According to Dariusz, such behavior is due to the communist values present in the Polish value system according to which "people are not allowed to do anything above average."

Dariusz has a very positive attitude towards Americans. He finds them hard working and "great to work with." He admits that the American way of life fits him better, because he knows that he can achieve a lot by working hard, while in Poland he will need connections to get a good job. Dariusz is appreciative of the fact that in the United States he has freedom of choice in matters such as religion. In Poland "not being Catholic is unpatriotic." Also, in the United States Dariusz can "avoid numerous pointless religious celebrations such as the first communion or confirmation" which he finds boring and sometimes embarrassing." Even though he enjoys his freedom in the United States, one thing that he finds "irreconcilable" with his Polish upbringing is American sport interests. Dariusz, similar to other Polish men, grew up playing soccer and watching soccer games of his favorite teams and the Polish national soccer team; he does not find American football or baseball appealing. Yet, he sees his lifestyle as American rather than Polish: he drives a car to work, he buys his lunch at work, and he works until late. In Poland he would presumably "take public transport, take lunch from home and come back from work by 4:00 or 5:00 PM." Overall, he thinks that his life in Poland would be "less stressful and slower but with fewer perspectives" than his life in 
the United States. Dariusz also sees differences between American and Polish attitudes about work. While Americans "go to college and choose a job that they actually want to do, Polish people work because they have to." As a result, Polish people do not make good workers because they lack dedication and because "they focus on family rather than work." Similarly, according to Dariusz, although Polish people claim to be patriotic, "they have no respect for law and order. They cheat the system and other people whenever nobody is looking." Dariusz identifies himself as Polish even though he admits that he does not make an effort to maintain Polish language and culture. He does not see any problem in this discrepancy and declares that he "just isn't a spiritual type of person who would cherish his identity." He prefers to merely live his life, making use of the opportunities he has been provided with.

\section{General Findings}

Listed below are general findings regarding the research questions identified earlier in this chapter. The findings describe informants' maintenance of Polish language and culture, intergenerational language transmission, and the factors that influence the maintenance and transmission of Polish language. The factors considered in the findings are listed in Chapter Two.

Use of Polish language. Home and friends are the main domains of Polish language use as identified in this study. Overall, home is the main domain where Polish language is being used. Those informants who do not have a chance to use Polish at 
home do not have many other opportunities to use it on a daily basis. The use of Polish at home depends on the native language of the spouse. The two informants who are married to other first generation Polish immigrants (Alina and Arek) generally speak Polish at home with their spouses and children. However, they also sometimes use English to communicate with their spouses and children.

All informants continue to use Polish to communicate with their families in Poland. One informant (Monika) states that she contacts her mother and sister every day. Others state that they contact their families on a weekly basis. The four female informants maintain contact with their friends in Poland; these four also have some Polish friends in the South Bay Area. Three female informants, Monika, Kasia, and Agnieszka, maintain monthly contact with one to three Polish speaking friends while three others say that they are not in touch with anyone.

Polish media are another tool that helps the informants to maintain their use of the Polish language. Three informants, Alina, Arek, and Monika, use media in Polish language a few times a month. Polish TV is the most popular form of Polish entertainment among the informants: two of them (Alina and Monika) watch Polish TV at least once a week and one (Arek) does it one to three times a month. Three informants (Alina, Arek, and Monika) regularly watch a Polish film at least one to three times in a month. Two informants (Alina, Monika) listen to Polish music or radio at least one to three times a month and two read Polish books or magazines. Three informants (Monika, Kasia, and Agnieszka) use Facebook and Skype in order to communicate with their friends and family in Poland. Thanks to the Internet, Monika is able to talk to her mother 
and sister every day, sometimes for a few hours at a time; since there is no charge, she can talk for as long as she wants to. Four informants (Alina, Arek, Kasia, and Monika) use the Internet to regularly read news and watch videos in Polish. However, only two informants (Alina and Monika) admit that they use Polish language media as often as English language media. Both of them admit that keeping this proportion allows them to remain fluent in Polish language.

When asked whether their proficiency in Polish has decreased after their prolonged stay in the United States, two informants (Kasia and Arek) state that their proficiency has decreased while two (Alina, Monika) say that it has not; three others (Agnieszka and Dariusz) do not have an opinion on that. Alina, who has been living in the United States for more than 30 years, is still fluent in Polish; her Polish is also free from American borrowings. She commented as follows:

I don't think that it's difficult to maintain fluent and clear Polish language while living abroad. Many Polish Americans whom I know don't care for the purity of Polish language; they use a lot of English words in place of Polish words. I don't do it and I never let my sons do it.

When asked whether they feel more comfortable speaking English than Polish, three informants, Alina, Arek, and Monika, say that they prefer Polish. Three others, Kasia, Agnieszka, and Darek, state that whether or not they use Polish depends on the context. As Kasia explains,

I rarely use Polish, maybe once in two weeks when I talk on the phone with my mother. I got used to using certain words in English and I want to use them in Polish, but, here is the problem, there are no equivalents so I feel like I'm losing 
my Polish but I also know that once I go back to Poland it will take me one day to switch back to Polish.

Agnieszka admits that she has a similar problem; however, she adds that when she visits Poland, it only takes her one or two days to "switch back to Polish."

Maintenance of Polish cultural traditions. Like Polish language, Polish immigrants in the South Bay Area are maintaining Polish culture mainly at home. They maintain Polish culture by celebrating major Polish holidays such as Christmas and Easter and cooking or buying Polish food. Five respondents (Alina, Arek, Monika, Kasia, and Agnieszka) celebrate Christmas and Easter and four (Alina, Arek, Monika, and Kasia) celebrate these holidays according to Polish traditions. During these holidays, these four informants also visit the Polish Mission in San Jose. Three informants (Arek, Kasia, and Agnieszka) note that they celebrate Christmas and Easter not only because they are the major Polish holidays but also because they are celebrated by Americans as well.

When asked about details of celebrating Christmas and Easter "in the Polish way," informants mention that they cook or buy Polish dishes, such as beetroot soup, fish, and dumplings for Christmas, and boiled egg, ham, sausage and sourdough soup for Easter; they also go to church on both occasions. Two informants (Alina and Monika) regularly attend the midnight service on Christmas Eve. Four informants (Alina, Arek, Monika, and Kasia) bring a basket with food for Easter blessings at the church. Four female informants celebrate their name days. However, none regularly celebrates other 
Polish holidays. Two informants mention that All Saint's Day is important to them but they can't celebrate it since their family graves are in Poland.

Catholicism plays an important part in the lives of Polish people, traditionally accompanying them during the milestones of their lives. One of the questions required the informants to answer whether their children had gone through or would presumably go through traditional Catholic ceremonies (such as baptism, first communion, and confirmation). Five informants (Alina, Arek, Monika, Kasia, and Agnieszka) note that they either baptized their children or they intend to do it. In contrast, Dariusz says that he does not plan to baptize his children. Two informants (Alina, Arek, and Monika) also state that their children received or will receive the sacrament of the first communion while three (Kasia, Agnieszka, and Dariusz) say that their children will presumably not receive it. Kasia comments on the issue as follows:

In Poland everybody is baptized, takes the first communion, confirmation, and marriage in church, but here it's just not a standard thing. In Poland you are left out if you don't participate in all those ceremonies. I didn't know anybody who didn't participate in the first communion and I only knew one person who didn't receive the confirmation. Here our children grow up in a multicultural society where anything is ok. I would like them to be aware of different religions, especially Christianity and Hinduism, because of me and my husband, but they don't have to follow them.

Only two informants (Alina and Monika) agree that religion occupies an important place in their lives. Two (Arek and Agnieszka) are undecided about it and two (Kasia and Dariusz) disagree. Alina, a woman in her early sixties, states that "the Catholic religion is an important part of my identity. It was important to people in Poland during the communist regime. Nowadays young people don't care about church. 
I grew up during those days so I have a different mentality.” Dariusz comments as follows: "I would say that religion played an important role in my upbringing but I'm not particularly believing or spiritual now so religion is not that important to me anymore." Two informants (Alina and Monika) state that they attend church (but not necessarily Polish church) every Sunday or almost every Sunday. Three informants (Arek, Kasia, and Agnieszka) go to church twice a year, and one (Dariusz) never attends church. Monika, who takes her one-year old daughter to church every Sunday says that it's important to her that her daughter gets used to attending and to being in church.

Eating Polish food is another way in which informants maintain Polish culture. Although all informants except Dariusz mention that they miss Polish food, only two (Alina and Monika) eat Polish food more than ten times per month; one (Arek) eats Polish food four to nine times per month. One (Kasia) eats it one to three times, and two (Agnieszka and Dariusz) don't eat any Polish food at all. Three female informants (Alina, Monika, and Kasia) note that they don't cook Polish food as often as they would like to, because Polish meals are heavy and rich. These respondents also state that compared to American meals Polish dishes generally take a lot of time to prepare. Five informants (all but Darek) know about the Polish restaurants and stores in the area; while the informants visit the restaurants only occasionally or not at all, they frequently shop in Slavic or European stores. Monika visits the stores on a weekly basis and Alina and Kasia do it on a monthly basis. The items that they normally purchase include Polish sweets, jams, pickles, bakery products, and deli products. However, even those who visit 
the Polish stores regularly admit that they only do minor shopping there because it is cheaper and more convenient to shop in big local stores such as Safeway or Trader Joe's.

Intergenerational transmission of Polish language and culture. Children are a major reason why informants want to continue speaking Polish in their homes. Four informants (Alina, Arek, Monika, and Kasia) agree that it is important to them that their children learn the Polish language because it will enable them to communicate with their grandparents and other family members in Poland. Kasia and Alina also say that Polish language is an integral part of "Polish identity," and so they want their children to speak Polish so that they can share a similar sense of identity. Out of five informants who have children, three (Alina, Arek, and Monika) claim that their children speak Polish fluently; one (Agnieszka) maintains that her children speak no Polish at all; and one (Kasia) says that her daughter knows only a little bit of Polish. Alina's, Monika's, and Arek's children spoke only Polish and no English at all until they went to school where they had to learn English. Kasia plans to teach her children Polish in the near future while Agnieszka and Dariusz don't have such a plan. Sunday school, summer visits to Poland, books, and TV (films and cartoons) are the most common ways by which informants teach their children Polish. The Internet is another preferred way of exposing children to Polish language. Other ways to teach children Polish include frequent meetings with Polish family members and friends. 


\section{The role of community factors in the maintenance of Polish language and}

culture. All six informants agree that the Polish community in the South Bay Area is small and unorganized and the few institutions that exist do not promote interaction among the community members. The Polish Catholic Mission in San Jose is one Polish organization that informants (except Dariusz) are familiar with; four of them have visited it at least once. When asked about whether they feel that they belong to a Polish community, three respondents (Alina, Arek and Monika) are unsure and three (Kasia, Agnieszka, and Dariusz) disagree. For example, Kasia states that she does not perceive herself as a part of any Polish or American community because her friends come from various countries. Also, a large number of her neighbors and family friends are Indian; therefore, she sees herself as part of an Indian community rather than an American community in the area. Interestingly, two informants, Monika and Arek, say that even though they officially belong to an American community, they do not perceive themselves as truly belonging to it. Monika comments that:

In Poland I had a feeling of being a part of a smaller community because I would meet my neighbors in the hall of the apartment building or on my way to the bus stop. There I felt that I was a part of a broader community because everybody would go to church on Sundays and stand in the line in a bakery before Easter or Christmas. Here I don't have that same sense of belonging.

All informants have some Polish friends or acquaintances in the South Bay Area, but these friendships play a vital role in their lives only for three of them (Alina, Monika, and Kasia, who know ten or more individuals or families). For instance, Kasia joined a group of eleven Polish women who are married to Indian men. Through a Facebook 
group they exchange information about Polish and Indian events, recipes, and other functional and fun information. They also hold regular meetings during which they watch Polish movies; they go out to cultural events, talk about their lives, and share their experiences. Like Kasia, Alina and Monika state that they have many Polish acquaintances. Only Monika indicates that the majority of her friends are Polish. Other than Kasia, Alina, and Monika, the other informants say that Polish friends and community events play only a marginal role in their lives. However, Kasia's example suggests that when a person has an opportunity to become a member of an organized Polish community group, he or she can regain connection with Polish language and culture. Clearly, the small size of the Polish community in the South Bay Area negatively influences the maintenance of Polish language and culture. If the Polish community in the Bay Area were bigger and better organized, there would be a need for more cultural organizations that would create opportunities for the maintenance of Polish language and culture through schools, libraries, cultural centers, clubs, stores, etc.

\section{The Role of demographic factors in the maintenance of Polish language and}

culture. The informants' length of stay in the United States seems to influence their maintenance of Polish language and culture. Not surprisingly, those informants who emigrated recently maintain closer contacts with their families and friends in Poland. For instance, Monika talks to her mother, sister, and two friends via Skype almost every day; Kasia and Agnieszka also maintain weekly contact with their families and the three of them also maintain monthly contact with their friends in Poland. In addition, Monika and 
Agnieszka say that they miss their families and friends, and that they want to visit them more often. In contrast, Alina and Arek have helped many members of their families move to the United States; therefore they contact their remaining relatives and friends once or twice a year only. According to Arek, with time his connections with Poland became weaker. Overall, those informants who emigrated to the United States recently have more connections with Poland than those who left the country more than twenty years ago, but the older immigrants who came to the United States more than 20 years ago are able to maintain Polish language and culture in their homes as successfully as recent immigrants. This may relate to different reasons for their immigration. While those who emigrated more than 20 years ago left Poland involuntarily for political reasons, those who emigrated less than 20 years ago left voluntarily. In this study, those Polish immigrants who left involuntarily for political reasons seem to hold on to Polish language and culture more than those who left voluntarily. They seem to make special effort to maintain Polish language and culture in their homes, even though with time their connections with Poland have become weaker. More recent immigrants, on the other hand, maintain stronger connections with family and friends in Poland; however, they do not make special effort to maintain Polish language and culture in their everyday lives.

The birthplace of the spouse is clearly a major factor determining the maintenance of Polish language and culture. The informants who married first generation Polish immigrants are likely to continue speaking Polish in their everyday lives and pass Polish language and culture to their children. Alina and Arek, whose spouses are Polish, successfully maintain Polish language and culture in their homes for more than 20 years 
and they have taught their children to speak Polish. Monika, whose husband is a secondgeneration Polish immigrant, also involves her husband and his mother in raising their daughter with the Polish language and culture. She frequently spends time with her husband's Polish family regularly speaking Polish and celebrating Polish holidays; the company of Polish grandparents and second-generation Polish cousins provides an additional opportunity for Monika's daughter to be exposed to Polish language and culture. Furthermore, Alina and Monika, who are married, respectively, to first and second generation Polish men, state that due to the fact that their husbands are Polish, their families are able to befriend and stay in touch with other Polish couples.

It seems that first generation Polish immigrants who are married to firstgeneration non-Polish immigrants are more likely to maintain their language and culture than first generation Polish immigrants married to Americans. For instance, Kasia, who is married to an Indian man, makes an effort to raise her children following Polish culture. It is very important for Kasia and her husband that their children learn both Polish and Bengali because neither of the parents identifies himself/herself with the American culture. They participate in a group of married first generation Polish and first generation Indian men. In my own visits to their group meetings I noticed that a few of the women who have children do an excellent job teaching their children Polish language and culture. Kasia reflects on the differences between marrying an American and marrying an immigrant:

It helps a lot when both of you are immigrants, even if you come from different countries and speak different languages because you have the same experience and you both will probably care to maintain some part of your culture in your 
house and make your children understand it. If I moved to India, I would probably have to adjust to the culture there and my children might not speak Polish in that situation.

Indeed, even though English is the main language used in Kasia's house, in a situation when neither the husband nor the wife speaks English as the first language, their native languages remain vital parts of their identities. In contrast, when one person in a couple speaks English (the language of the host society) as a first language, the other person may see little value in maintaining the Polish language.

In this study, compared to male informants, female informants prefer to maintain contact with friends and family in Poland, and they are more determined to maintain Polish culture in their homes and to pass Polish language and culture to their children. Neither of the two male participants in the study maintains monthly contact with friends in Poland; in contrast, all the female participants maintain some degree of contact with their families: four participants have contact more than once a week, one participant communicates once a week, and three participants maintain monthly contact with one to three friends in Poland. Polish women, Alina, Kasia, and Agnieszka, also use the Internet, mainly Facebook, Nasza Klasa (the Polish equivalent of Classmates.com) and Skype, to stay in touch with their friends in Poland.

In spite of their high level of education, the informants do not have any interest in providing leadership in the Polish community. Only Alina used to work as a teacher in a Polish school. She was also the only one who expressed her concern about the purity of the Polish language. High level of education combined with high proficiency in English has allowed the informants to function within American society without needing to attain 
any assistance from other Polish immigrants. All informants in this study had a high (three subjects) or intermediate (three subjects) level of proficiency in English when they first came to the United States. As a consequence, all of them were able to function in American society without the help of a Polish community.

\section{The role of attitudes and perceptions in the maintenance of Polish language}

and culture. The subjects who have lived in the United States for more than ten years claim with more certainty that they have an American cultural identity. For Alina and Arek the fact that they hold American citizenship implies that they have an American cultural identity. However, for Kasia and Monika the fact that they are American citizens does not mean that they readily accept American cultural identity. They note that in spite of the fact that they live here, the United States is still a foreign country to them. On the other hand, declaring Polish identity by itself does not necessary imply that the immigrants will maintain Polish language and culture. For example, Alina declares that her identity is both Polish and American, but she maintains Polish language and culture better than other informants in this study who declare their identity to be only Polish.

In general, the informants see Polish and American cultures as highly compatible. This compatibility makes it easier for them to adopt American lifestyle and embrace American values. They admit that they accept American values and reconcile the differences between Polish and American value systems. Monika and Kasia explain that the two Polish values that they consider to be important in their lives are involvement with family and hospitability; however, they did not have trouble adopting American values. Alina and Kasia prefer Polish education to American education but they also 
admit that the United States has some of the best colleges in the world. Alina dislikes American eating habits but she admits that Polish cuisine is heavy. Clearly, there are certain elements of Polish culture that the informants prefer to give up. Alina, Monika, Agnieszka, and Dariusz dislike Polish pessimism and the overall negativity of Polish people, which expresses itself in the habit of complaining. They think that American optimism is a better approach to life. In addition, Dariusz and Arek mention that they dislike how in Poland pessimism and lack of faith in one's own ability get translated into lack of progress in people's lives and in their work. In the United States, on the other hand, Dariusz and Arek feel motivated to work and they know that they will be rewarded for good work. Like Arek and Dariusz, Agnieszka says that Polish people should become more self-confident and risk-taking, the way Americans are, because these characteristics can help them to succeed in life. Monika likes American gender roles more than Polish gender roles and she prefers that her husband help her to do household chores.

Adopting American values goes hand in hand with informants' positive attitudes towards Americans. All of them are happy with their lives in the United States; four indicate that they live a better life in the United States than they would live in Poland. Also, all of them state that they perceive the South Bay Area as an immigrant-friendly place. At the same time, the informants in this study have positive attitudes towards Polish people, although a few of them point out that they dislike certain characteristics in them (such as the habit of complaining). Overall, all informants have positive attitudes towards American people and culture, and this attitude certainly helped them to adapt to the American lifestyle. In contrast, all informants express some degree of criticism about 
Polish people. Those who point out more positive aspects of Polish culture (Alina, Monika) maintain Polish language and culture better than others. 


\section{Chapter Five: Conclusions and Direction for Further Research}

My aims in this study were to find out to what extent Polish language and culture are being practiced by first generation Polish immigrants living in the South Bay Area of California, what variables influence Polish language and culture maintenance, and to what extent Polish language and culture are being passed to the second generation. The first generation Polish immigrants living in the South Bay Area that I interviewed for this study maintain Polish language and culture to varying degrees. This study shows that the small size of the Polish community is a major factor that prevents Polish immigrants from maintaining their language and culture. As a result, the maintenance of Polish language and culture among first generation Polish immigrants and intergenerational language transmission happen mainly at home among family members, if at all. The Polish community in the South Bay Area is a relatively small group compared to its neighboring Indian, Chinese, Vietnamese, Korean, and Hispanic communities, and its small size has a negative impact on the maintenance of Polish language and culture. The few Polish community organizations in the South Bay Area do not create enough occasions for Polish immigrants to interact with each other. Even if Polish people in the area want to use the Polish language and practice Polish culture, it is often not possible because there exist few opportunities. For example, there is only one Polish church in the South Bay Area. Although the church offers Polish classes to children, and although it serves Polish food on Sundays, the church does not have a wide impact on promoting Polish language and culture among the Polish immigrants in the area simply because it is 
just one small church in a very populated area. At most, the church serves as a hub for only a few people in the Polish community. Some Polish informants in this study prefer to visit local American churches, because they believe that what the Polish Catholic church has to offer is not worth the long commute. Overall, there are not many other institutions available to promote the maintenance of Polish language and culture. The lack of Polish schools has a negative impact on the maintenance of Polish language in the second generation. It is clearly important to Polish immigrants in the South Bay Area that their children speak Polish, but apart from speaking Polish at home there is very little that parents can do to teach their children Polish. Even if parents prefer to enroll their children in full-time Polish schools or classes, no such options are available.

Some informants in this study mention that to promote Polish language it is necessary to have a united community effort. However, the Polish community in the area lacks leaders willing to create community initiatives, even though there is a need for them. Churches have traditionally served as a fulcrum for communities. In fact, Parot (1981) and Zaniecki-Lopata (1976) mention that historically parishes performed an important role in uniting Polish immigrant communities in Chicago, for example. However, as informants in this study emphasize, parishes may not be as effective in that role because the fourth wave of Polish immigrants to the United States has moved away from religion; therefore it is important to have organizations other than churches to unite Polish immigrant communities.

When it comes to media, there are very few resources available in local libraries; the one medium easily available is the Internet, which is a rich source that Polish 
immigrants utilize to watch Polish TV, listen to Polish radio, read news about Poland, and communicate in the Polish language. The Internet proved to be an important linguistic resource for cohering the Polish community wherever they live. As Fitzgerald et al. (2006) point out and as this study indicates, the Internet helps immigrants to stay more connected with their home countries than ever before. Thanks to the Internet, Polish language resources are readily available than ever before: with Polish online newspapers, TV and radio it is easy to stay updated about events in Poland. Furthermore, the Internet allows immigrants to maintain contact with friends and family. Skype makes free unlimited video calls possible, while social networking sites allow people to write to their friends and stay connected by following their posts and photographs. Of course, accessing and using the Internet is an individual effort that does not necessarily replace human interaction with other Polish immigrants.

In the absence of a united community effort to promote Polish language and Polish culture among Polish immigrants in the South Bay Area, family facilitates the maintenance of language and culture. Pienkos (1997) suggests that in the absence of cohesive institutions and activities, family and social networks can provide opportunities for Polish immigrants to maintain Polish language and culture. For example, Polish women make Polish language and culture present in their lives through frequent telephonic contact and visits with family and friends. However, due to the rapid and demanding pace of life in the South Bay Area, these connections do get weaker and they may eventually dissolve with time. 
This study indicates that in a small community like the Polish community in the South Bay Area the ethnic background of the spouse plays a major role in the maintenance of Polish language and culture and in passing the language onto the second generation. Similarly, Janik (1996) and Leuner (2007) point out that the greatest use of Polish in the Polish community in Australia was at home in endogamous families, mainly between spouses and between parents and their offspring. Like the findings by Janik (1996) and Leuner (2007), this study also shows that those married to other Polish immigrants maintain Polish language and culture better than those who are not married to Polish immigrants. Yet, there are exceptions in my study. For example, Monika is married to a second-generation Polish immigrant and since her husband speaks very little Polish, Monika communicates with him primarily in English. However, Monika speaks Polish almost exclusively with her daughter; her husband also makes an effort to speak Polish with his daughter. Monika's in-laws, living nearby, create a support network for Monika by teaching Polish to Monika's daughter and by organizing Polish family celebrations. Janik (1996) also points out the role of the grandparents in intergenerational language transmission.) Another exception in my study is the case of Kasia: both she and her husband are first generation immigrants but they belong to different ethnic groups. Because they are both immigrants, maintaining elements of their native cultures at home is important to them; teaching their children Polish and Bengali is a priority. Kasia maintains what Gans (1979) calls "symbolic identity": her Polish identity has an expressive but not instrumental function. In contrast, Agnieszka, who is married to an American man, is not interested in maintaining Polish culture or teaching Polish language 
to her children. While this study notices the efforts made by Polish immigrants whose spouses are immigrants from other countries, it is not clear whether these efforts will transform into long-lasting results. Other research notes this uncertainty: Kravin (1992) points out that the input of one parent alone is not enough for one's L1 to fully develop, and Batibo (2005) states that intermarriage in general favors the use of a common language of the spouses. In contrast, Guardado (2002) claims that some of his informants did develop language skills in one of their parents' L1. In addition, Leuner (2007) claims that in the case of the exogamous marriages that he analyzed, of those who continue following Polish traditions and maintaining Polish language and culture, the wife, not the husband, was always Polish. My study confirms that Polish women are more likely than their husbands to cultivate Polish traditions in the family and transmit Polish language to their offspring.

My study shows that there are two significant factors that allow first generation Polish immigrants in the South Bay Area to function in the United States with minimal help from other Polish immigrants or a Polish community: their competent knowledge of English at time of arrival and their high level of education. All of the informants in my study arrived in the South Bay area with some proficiency in English. While some communist-era immigrants might have come to the United States without knowing English, more recent immigrants have at least intermediate knowledge of the language, because after the fall of communism in Poland English became one of the main subjects taught in all schools. In addition to the fact that all the informants were fluent in English, they also had a relatively high level of education at the time of arrival in the United 
States. These two factors allowed them to earn the respect of the American society and to gain a comfortable position in it. Performing relatively prestigious jobs, the informants have merged into the mainstream and have experienced virtually no problems while becoming apparently indistinguishable from native-born Americans. In addition, their phenotype has not presented itself as an impediment. Psychological factors might also play a part: perceiving the host society as welcoming, these informants feel that they fit in, and they have willingly embraced American values, such as optimism, which they markedly prefer over Polish pessimism.

To sum up, in this small Polish immigrant community in the South Bay Area maintenance of Polish language and culture happens primarily at home, in endogamic marriages among spouses and children. The small size of this Polish community, knowledge of English at the time of arrival, and high level of education together contribute to first generation Polish immigrants' shift to English language and American culture.

The small scale of this study and its preliminary findings call for further research regarding first generation of Polish immigrants in the South Bay Area. A longitudinal quantitative study including a larger pool of participants would clarify the preliminary findings in this study and could provide further insights about the factors that affect and help to determine the degree to which Poles maintain their language and culture. In addition, this study raises new questions: it outlines a profile of the fourth wave of Polish immigrants to the United States and it reveals some significant differences between the third wave of communist-era immigrants and the fourth wave of post-communist 
immigrants. For example, older immigrants (such as Alina and Arek) seem to stay more attached to Polish culture than the recent immigrants (such as Dariusz). Poland has a long history of suppression, and during World War I and World War II the culture was infused with an almost hyper-patriotic sensibility that permeated people's lives. Presently, with the rise of the Internet many young Polish people prefer to take up a global identity rather than Polish national identity. The latter trend may be true about the immigrants who arrived more recently; they grew up in capitalist Poland and in the era of globalization and were more exposed to factors shaping global rather than national identity. In contrast, the older immigrants were raised in a more traditional communist Poland. Thus, while more recent immigrants may find it easier to adjust to the American lifestyle and values, the older immigrants may find it to be more challenging. This is especially true in light of the fact that during the communist regime many Polish nationals left their country for political reasons: they mostly left capitalist Poland voluntarily and were motivated by curiosity about the world and by potential material gains. The latter may be more inclined to take up American lifestyle and values. Overall, with globalization and democratization as identity-shaping processes, the fourth wave Polish immigrants come across as more like Americans and thus they may find it relatively easy to accept American values. My study highlights this important factor in how Polish immigrants in the South Bay Area maintain Polish language and culture, but certainly, further, more in-depth research with a wider pool of informants is necessary to understand the differences between first generation Polish immigrants who belong to the third wave and those who belong to the fourth wave of immigration. 


\section{References}

About Polish Immigrants. (October 20, 2002). Nasz Dziennik. Retrieved from http://www.naszdziennik.pl/archiwum.php?typ=ii\&dat=20110617\&id=main

Allard, R., \& Landry, R. (1994). Subjective Ethnolinguistic Vitality: A Comparison of Two Measures. International Journal of Sociology of Language, 108, 117-144.

Batibo, H. M. (2005). Language decline and death in Africa: Causes, consequences and challenges. Clevedon: Multilingual Matters.

Berry, J. W. (2001). A psychology of immigration. Journal of Social Issues, 57(3), 615631.

Berry, J. W. (2005). Acculturation: Living successfully in two cultures. International Journal of Intercultural Relations, 29, 697-712.

Blejwas, S. (1981). Old and new Polonians: Tension within an ethnic community. Polish American Studies, 38(2), 55-83.

Chinen, K., \& Tucker, G.R. (2006). Understanding the roles of ethnic identity, schooling and community. In K. Kondo-Brown (Ed.), Heritage language development: Focus on East Asian immigrants (pp.89-110). Amsterdam, NLD: John Benjamins Publishing Company.

Clement, R. (1980). Ethnicity, contact and communicative competence in a second language. In H.Giles, P.Robinson, and P.Smith, (Eds.), Language: Social psychological perspectives. Oxford: Pergamon.

Dutkova-Cope, L. (2003). Texas Czech ethnic identity: So how Czech are you, really? The Slavic and East European, 47(4), 648-676.

Erdmans, M. P. (1995). Immigrants and ethnics: Conflict and identity in Chicago Polonia. The Sociological Quarterly, 36 (1), 175-195.

Erdmans, M.P. (1998). Opposite Poles: Immigrants and ethnics in Polish Chicago, 19761990. University Park: The Pennsylvania State University Press.

Festinger, L. (1957). A theory of cognitive dissonance. Stanford, CA: Stanford University Press.

Fishman, J. (Ed.) (1966). Language loyalty in the United States. The Hague: Mouton. 
Fishman, J. (1972). Language maintenance and language shift as a field of inquiry: Revisited. In Language in sociocultural change. Stanford: Stanford University Press (pp. 76-134).

Fishman, J. (1977). The social science perspective. In: Billingual education: Current perspectives Vol .1 (pp. 1-49): Social science. Arlington: Centre for Applied Linguistics.

Fishman, J. (1991). Reversing language shift: Theoretical and empirical foundations of assistance to threatened languages. Clevedon: Multilingual Natters.

Fitzgerald, M., et al. (2006). Internet use of Polish by Polish Melburians: Implications for maintenance and teaching. Language Learning \& Technology, 10(1), 87-109.

Galush (1996). Polish Americans and religion. In J. J. Bukowczyk (Ed.), Polish Americans and their history: Community, Culture and Politics (pp. 80-92). Pittsburgh: University of Pittsburgh Press.

Gans, H. J. (1979). Symbolic Ethnicity: The future of ethnic groups and cultures in America. Ethnic and Racial Studies, 2(1), 1-20.

Gibbons, J., \& Ramirez, E. (2004). Maintaining a minority language: a case study of Hispanic teenagers. Clevedon: Multilingual Matters.

Guardado, M. (2002). Loss and maintenance of first language skills: Case studies of Hispanic families in Vancouver. The Canadian Modern Language Review/La Revue Canadienne des Langues Vivantes, 58(3), 341-363.

Hamers, J. F., \& Blanc, M. H. A. (2000) Bilinguality and bilingualism (2nd ed). Cambridge, UK: Cambridge University Press.

Hayashi, A. (2006). Japanese English bilingual children in three different educational environments. In K. Kondo-Brown (Ed.), Heritage Language Development: Focus on East Asian Immigrants (pp.146-171). Amsterdam, NLD: John Benjamins Publishing Company.

Janik, J. (1996). Polish language maintenance of the Polish students at Princess Hill Saturday School in Melbourne. Journal of Multilingual and Multicultural Development, 17(1), 3-15.

Kim, H. J. (2006). Heritage language maintenance by Korean-American college students. In K. Kondo-Brown (Ed.), Heritage language development: Focus on East Asian immigrants (pp.176-208). Amsterdam, NLD: John Benjamins Publishing Company. 
Kramsch, C. (1998). Language and culture. New York: Oxford University Press.

Kravin, H. (1992). Erosion of a tongue in bilingual development. Journal of Multilingual and Multicultural Development, 13, 307-325.

Kulniczak, S. (1978). Polonia: The face of Poland in America. American Heritage, 29 (3), 34-44.

LaFromboise, T., Coleman, H. L .K., \& Gerton, J. (1993). Psychological impact of biculturalism: Evidence and theory. Psychological Bulletin, 114(3), 395-412.

Leuner, B. (2007). Language maintenance in a new culture. Case study: Polish migrants from the 1980s in Melbourne. Glottodidactica, 33, 147-160.

$\mathrm{Li}$, G. (2006) The role of parents in heritage language maintenance and development. In K. Kondo-Brown (Ed.), Heritage language development: Focus on East Asian immigrants, (pp.15-32). Amsterdam, NLD: John Benjamins Publishing Company.

Luo, S. H., \& Wiseman, R. L. (2000). Ethnic language maintenance among Chinese immigrant children in the United States. International Journal of Intercultural Relations 24(3), 307-324.

Merino, B. (1983). Language loss in bilingual Chicano children. Journal of Applied Developmental Psychology, 4, 277-294.

Norton, B. (1998). Rethinking acculturation in second language acquisition. PROSPECT: Australian Journal of TESOL Associations, 13(2), 4-19.

Parot, J. J. (1981). Polish Catholics in Chicago, 1850-1920. DeKalb: Northern Illinois University Press.

Pienkos, D. (1997). Ethnic orientations among Polish Americans. International Migration Review, 11( 3), 350-362.

Portes, R. G., \& Rumbaut, A. (2001). Legacies: the story of the immigrant second generation. Berkeley: University of California Press, New York: Russell Sage Foundation.

Radziwilowski (1996). Family, women and gender: The Polish experience. In J. J. Bukowczyk (Ed.), Polish Americans and their history: Community, culture and politics (pp 59-79). Pittsburgh: University of Pittsburgh Press. 
SCC GOV: County of Santa Clara (2011). Retrieved June 16, 2011, from http://www.sccgov.org

Schecter, S., \& Bayley, R. (1997). Language socialization practices and cultural identity: Case studies of Mexican-descent families in California and Texas. TESOL Quarterly, 31, 513-541.

Schmid, M. S. (2002). First language attrition, use, and maintenance: The case of German Jews in anglophone countries. Amsterdam: John Benjamins.

Schumann, J. (1978). The acculturation model for second language acquisition. In R.C. Gingras (Ed.), Second language acquisition and foreign language teaching (pp. 27-50). Washington D.C.: Center for Applied Linguistics.

Shin, S. J. (2006). High-stakes testing and heritage language maintenance. In K. KondoBrown (Ed.), Heritage language development: Focus on East Asian immigrants (pp.128-144). Amsterdam, NLD: John Benjamins Publishing Company.

U.S. Census Bureau. (2000). Census 2000. Retrieved June 16, 2011, from http://www.census.gov

Yamamoto, M. (2001). Language use in interlingual families: A Japanese-English sociolinguistic study. Clevedon: Multilingual Matters.

Yamamoto, M. (2002). Language use in families with parents of different native languages: an investigation of Japanese-non-English and Japanese-English families. Journal of Multilingual and Multicultural Development, 23(6), 531-554.

Ying, Y-W. (1995). Cultural orientation and psychological well-being in Chinese Americans. American Journal of Community Psychology, 23(6), 893-911.

Zaniecki-Lopata, H. (1976). Polish Americans: Status competition in an ethnic community. New Jersey: Prentice-Hall.

Zhang, D. (2008). Between two generations: Language maintenance and acculturation among Chinese immigrant families, El Paso: LFB Scholarly Pub. 


\section{Appendix A: Interview Questions}

1. Why and in what circumstances did you leave Poland and come to the United States? Was it difficult for you to get used to living in the new country?

2. How large is the Polish community in your area? What Polish organizations are available (churches, cultural centers, stores, etc.)? Do you participate in the Polish community? If yes, then how? If not, then why not?

3. What resources (books, radio, television, Internet) in Polish language are available to maintain Polish is your area? Which of them do you utilize?

4. In your everyday life, do you maintain Polish culture? If yes then how? If not, why? Do you celebrate Polish holidays? For instance, do you celebrate Christmas in a traditionally Polish way? Do you maintain any other Polish traditions or customs?

Do other Poles that you know in the area maintain Polish language and culture?

5. Do you think that your lifestyle is different from American lifestyle? If yes, how?

What traditional Polish values do you consider important? Would you say that the major values that you cherish are Polish or American? Or would you say that Polish and American values are similar?

6. Do you feel Polish, American or both? Which element of your identity do you value more? Do you feel that your cultural identity depends on a situation? 
7. What is your attitude towards Poland and Polish people? Do you have many Polish friends? What is your attitude towards Americans? Do you have many American friends?

8. In your opinion, do Polish immigrants in the area perform prestigious jobs? What jobs do those people whom you know do? Are most of Polish immigrants in the area legal or illegal immigrants? Do you identify yourself with other Polish immigrants in the area? 


\section{Appendix B: Questionnaire}

Please, checkmark to choose your answer.

1. Gender

Male

Female

2. Approximately, how many years have you been living in the United States?

$\square$ Less than 10 years

10 -20 years

$\square$ 20-30 years

More than 30 years

3. Choose the age group in which you came to the United States.

$\square$ Below 16 years old

16-20 years old

$\square$ 21-30 years old

31-40 years old

$\square$ Older than 40 years old

4. With whom did you come to the United States?

$\square$ With parents

$\square$ With siblings

$\square$ With a spouse

$\square$ With a friend

$\square$ By yourself

Other

5. When you or your family first came to the United States, did you have an intention to settle in the United States?

Yes

$\square$ No

6. What motivated you or your family to come to the United States (check all that apply)?

Better education

Better job opportunities

$\square$ Better economic status

$\square$ Political freedom 


\section{Medical reasons \\ Vacation}

Other

7. What was your level of proficiency in English language when you came to the US?

$\square$ Proficient

Intermediate

Beginner

I did not know any English

8. What was the level of education that your parents acquired in Poland?

Father Mother
Elementary school
Vocational school
High school diploma
Some college
College graduate BA
College graduate MA or higher
I don't know

9. What was your level of education when you came to the United States?

Pre-elementary

Elementary school

Vocational school

High school diploma

Some college

College graduate BA

College graduate MA

10. What is your current level of education?

Elementary school

Vocational school

High school diploma

Some college

College graduate BA

College graduate MA 
11. How often do you speak Polish in your everyday life?
Home
Friends
Work

$\begin{array}{lll}\square & \square & \square \\ \square & \square & \square \\ \square & \square & \square \\ \square & \square & \square \\ \square & \square & \square\end{array}$
Always (100\%-90\%)
Often $(94 \%-70 \%)$
Sometimes $(69 \%-40 \%)$
Rarely $(39 \%-10 \%)$
Never $(10 \%-0 \%)$

12. How often do you speak English in your everyday life?

$\begin{array}{llll}\text { Home } & \text { Friends } & \text { Work } & \\ \square & \square & \square & \text { Always (100\%-90\%) } \\ \square & \square & \square & \text { Often (94\%-70\%) } \\ \square & \square & \square & \text { Sometimes (69\%-40\%) } \\ \square & \square & \square & \text { Rarely (39\%-10\%) } \\ \square & \square & \square & \text { Never (10\%-0\%) }\end{array}$

13. How often do you speak Polish with your Polish family and friends?

Always (100\%-90\%)

Often $(94 \%-70 \%)$

Sometimes $(69 \%-40 \%)$

Rarely $(39 \%-10 \%)$

Never $(10 \%-0 \%)$

14. How often do you speak English with your Polish family and friends?

Always (100\%-90\%)

Often $(94 \%-70 \%)$

Sometimes $(69 \%-40 \%)$

Rarely $(39 \%-10 \%)$

Never $(10 \%-0 \%)$

15. Are you married?

$\square$ Yes (answer questions 18 and 19)

$\square$ No (skip questions 18 and 19)

16. What nationality is your spouse?

Polish

American

Other 
17. Does your spouse speak Polish fluently?

$\square$ Yes

$\square$ No

18. Marrying a Polish person is important to me.

Strongly agree

Agree

Undecided

Disagree

Strongly disagree

19. What ethnicity are the majority of your friends?

Polish

American

Other

20. How many Polish families and/or single individuals do you know in your area?

$\square 0$

$\square 1-3$

$4-6$

7-9

10 or more

21. Excluding your family, how many friends in Poland did you contact at least once during last month?

0 friends

1-3 friends

4-6 friends

7 or more friends

22. What means do you employ to contact your family and friends in Poland (check all that apply)?

Family

Friends

$\begin{array}{lll}\square & \square & \text { Phone } \\ \square & \square & \text { Skype } \\ \square & \square & \text { E-mail } \\ \square & \square & \text { Letters } \\ \square & \square & \text { Other }\end{array}$

23. Maintaining Polish culture in my home is important to me.

Strongly agree 


\section{Agree \\ Undecided \\ Disagree \\ Strongly disagree}

24. How many times have you visited Poland during the last 9 years?

$\square 0$ times

$\square$ 1-2 times

$\square$ 3-5 times

$\square$ 6-9 times

$\square 10$ or more

25. It is important to me that my children learn Polish.

$\square$ Strongly agree

Agree

$\square$ Undecided

$\square$ Disagree

$\square$ Strongly disagree

26. Do you have children?

$\square$ Yes (answer questions 29 and 30)

$\square$ No (skip question 29 and 30)

27. Do your children speak Polish?

$\square$ Yes

Only a little bit

$\square$ No

28. From what sources did/do you teach your children Polish language and culture (circle all that apply)?

$\square$ Speaking Polish at home

$\square$ Polish school

Sunday school

$\square$ Summer visits in Poland

$\square$ Books

$\square \mathrm{TV}$

$\square$ Internet

$\square$ Others 
29. Have your children undergone the following:

Yes No Maybe

Catholic baptism

First Communion

Confirmation

If you don't have children or your children are little, do you expect that they will go through these milestone ceremonies?

30. Catholic religion occupies an important place in my life.

$\square$ Strongly agree

Agree

Undecided

Disagree

Strongly disagree

31. I feel that I am a part of a Polish community where I live.

$\square$ Strongly agree

Agree

Undecided

Disagree

Strongly disagree

32. As far as you know, is there any influential Polish community leader in the United States or South Bay Area?

$\begin{array}{lll} & \text { South Bay Area } & \text { US } \\ \text { Yes } & \square & \square \\ \text { No } & \square & \square\end{array}$

33. I feel that I am a part of an American community where I live.

Strongly agree

Agree

Undecided

Disagree

Strongly disagree

34. I am living a better life in the US than I would have lived in Poland.

Strongly agree

Agree

Undecided

Disagree 
Strongly disagree

35. How often do you celebrate Polish holidays such as Easter or Christmas?

Always (100\%-90\%)

Often $(94 \%-70 \%)$

Sometimes (69\%-40\%)

Rarely (39\%-10\%)

Never $(10 \%-0 \%)$

36. How often do you celebrate American holidays such as Thanksgiving?

Always (100\%-90\%)

Often $(94 \%-70 \%)$

Sometimes (69\%-40\%)

Rarely (39\%-10\%)

Never $(10 \%-0 \%)$

37. How often do you participate in Polish cultural events?

Always (100\%-90\%)

Often $(94 \%-70 \%)$

Sometimes (69\%-40\%)

Rarely (39\%-10\%)

Never $(10 \%-0 \%)$

38. How often do you participate in American cultural events?

Always (100\%-90\%)

Often $(94 \%-70 \%)$

Sometimes $(69 \%-40 \%)$

Rarely (39\%-10\%)

Never $(10 \%-0 \%)$

39. During past year how many times have you visited the Polish church in San Jose?

0 times

1-2 times

3-5 times

6 times or more

40. During past month how many times did you eat Polish food?

0 times

1-3 times

$\square$ 4-9 times 
$\square 10$ times or more

41. During past month how many times did you listen to Polish music?

$\square 0$ times

$\square$ 1-3 times

$\square$ 4-9 times

$\square 10$ times or more

42. During past month how many times did you watch Polish films?

$\square 0$ times

$\square$ 1-3 times

$\square$ 4-9 times

10 times or more

43. During past month how many times did you listen to Polish radio?

0 times

$\square$ 1-3 times

4-9 times

10 times or more

44. During past month how many times did you watch Polish TV?

$\square 0$ times

$\square$ 1-3 times

4-9 times

$\square 10$ times or more

45. During past month how many times did you read Polish books/magazines?

0 times

1-3 times

4-9 times

10 times or more

46. I stay updated about the news in Poland.

$\square$ Strongly agree

Agree

Undecided

Disagree

Strongly disagree 
47. I have a strong Polish identity.

$\square$ Strongly agree

Agree

$\square$ Undecided

$\square$ Disagree

$\square$ Strongly disagree

48. I have a strong American identity.

$\square$ Strongly agree

Agree

Undecided

Disagree

Strongly disagree

49. Do you feel more comfortable speaking Polish or English?

Polish

English

Depends on the context

50. Has your proficiency in Polish decreased?

$\square$ Yes

$\square$ No

$\square$ Undecided

51. In my opinion, people in South Bay Area respect cultural diversity.

$\square$ Strongly agree

$\square$ Agree

$\square$ Undecided

$\square$ Disagree

Strongly disagree

52. In order for a person to be a Polish American he or she needs to speak Polish language.

$\square$ Strongly agree

Agree

Undecided

Disagree

Strongly disagree 
53. In your life, what comes first, career or family?

$\square$ Career

Family

$\square$ It's hard to say

54. In your opinion, what comes first for Americans, career or family?

$\square$ Career

$\square$ Family

$\square$ It's hard to say

55. On a scale $1-5$, how would you describe compatibility between Polish and American cultures?

Incompatible $\square 1 \quad \square 2 \square 3 \quad \square 4 \square 5$ Very compatible

56. What is the name of the current president of Poland?

57. What is the name of a current popular Polish singer/music band? 


\section{Appendix C: Human Subjects Committee Letter of Approval}

SAN JOSÉ STATE UNIVERSITY

Division of Academic Affairs

Associate Vice President Graduate Studies \& Research

www.sjsu.edu/gradstudies

One Washington Square San José, California 95192-0025 Voice: 408-924-2427 Fax: 408-924-2612

www.sjsu.edu
To: Dominika Bialek

From: Pamela Stacks, Ph.D. Associate Vice President Graduate Studies and Research

Date: July 7, 2011

The Human Subjects-Institutional Review Board has approved your request to use human subjects in the study entitled:

"Maintenance of Polish language and culture among the first generation Polish immigrants in South Bay Area, California"

This approval is contingent upon the subjects participating in your research project being appropriately protected from risk. This includes the protection of the confidentiality of the subjects' identity when they participate in your research project, and with regard to all data that may be collected from the subjects. The approval includes continued monitoring of your research by the Board to assure that the subjects are being adequately and properly protected from such risks. If at any time a subject becomes injured or complains of injury, you must notify Dr. Pamela Stacks, Ph.D. immediately. Injury includes but is not limited to bodily harm, psychological trauma, and release of potentially damaging personal information. This approval for the human subject's portion of your project is in effect for one year, and data collection beyond July 7, 2012 requires an extension request.

Please also be advised that all subjects need to be fully informed and aware that their participation in your research project is voluntary, and that he or she may withdraw from the project at any time. Further, a subject's participation, refusal to participate, or withdrawal will not affect any services that the subject is receiving or will receive at the institution in which the research is being conducted.

If you have any questions, please contact me at (408) 924-2427.

Protocol \# S1102150

cc. Swathi Vanniarajan

0093 


\title{
Appendix D: Consent Form for Participants
}

\author{
Consent Form \\ Agreement to Participate in Research
}

\section{SanJosé State \\ UNIVERSITY}

College of Humanities and the Arts

Department of Linguistics and Language Development

Dr. Swathi Vanniarajan Professor \& Chair Voice: 408-924-3742 Fax: 408-924-4703

One Washington Square San José, California 95192-0093

The California State University: Chancellor's Office Bakersfield, Chico, Dominguez Hills, Fresno, Fullerton, Hayward, Humboldt Long Beach, Los Angeles, Maritime Academy, Monterey Bay, Northridge, Pomona, Sacramento, San Bernardino, San Diego, San Francisco, San José, San Luis Obispo, San Marcos, Sonoma, Stanislaus
Responsible Investigator: Dominika Bialek, graduate student in San Jose State University

Title of Study: Maintenance of Polish language and culture among the first generation Polish immigrants in South Bay Area, California.

1. You have been asked to participate in a research study investigating the maintenance of Polish language and culture among the first generation Polish immigrants in South Bay Area, California. You have been asked to participate in this study because you are an adult Polish immigrant.

2. You will be asked to answer a number of questions and fill out a questionnaire. Both together will take no more than an hour. All of the questions will be related to the topic of the study. The oral interview will be audio recorded for the purpose of transcription. The collection of data will take place in July and August 2011 in the place of your choice.

3. The possible risk for a participant in this research is emotional or psychological discomfort which may accompany expressing issues related to language and culture. On the other hand, there are potential benefits of participating in this study. One potential benefit is that the participant gains a better understanding of his or her cultural identity. Another potential benefit is that the participant gains a better understanding of the factors that contribute to language and culture maintenance.

4. Although the results of this study may be published, no information that could identify any of the participants will be included. Your name will be kept confidential. The materials will be organized using pseudonyms and no real name of any of the participants will be disclosed. The audio recordings will be immediately transcribed and deleted. The Word document files will be kept on my personal computer to which no third party has access.

Initial 
5. There is no compensation for participating in this study.

6. Questions about this research may be addressed to Dominika Bialek at (408) 507-3390 or through email iana_b@hotmail.com. If I am not available, please leave a message and I will get back to you immediately. Alternatively, you can contact my advisor, Dr. Swathi Vanniarajan, at (408) 924-3742 or swathi.vanniarajan@sjsu.edu. Complaints about the research may be presented to the Chair of the Linguistics and Language Development Department, Dr. Swathi Vanniarajan at (408) 924-3742 or swathi.vanniarajan@sjsu.edu. Questions about a research subjects' rights, or research-related injury may be presented to Pamela Stacks, Ph.D., Associate Vice President, Graduate Studies and Research, at (408) 924-2427.

7. No service of any kind, to which you are otherwise entitled, will be lost or jeopardized if you choose not to participate in the study.

8. Your consent is being given voluntarily. You may refuse to participate in the entire study or in any part of the study. You have the right to not answer questions you do not wish to answer. If you decide to participate in the study, you are free to withdraw at any time without any negative effect on your relations with San Jose State University.

9. At the time that you sign this consent form, you will receive a copy of it for your records, signed and dated by the investigator.

- Your signature on this document indicates agreement to participate in the study.

- The signature of a researcher on this document indicates agreement to include the above named subject in the research and attestation that the subject has been fully informed of his or her rights.

Participant's Signature Date

Investigator's Signature Date 